\title{
Cytokines and junction restructuring during spermatogenesis-a lesson to learn from the testis
}

\footnotetext{
* Corresponding author. Tel.: +1 212327 8738; fax: +1 2123278733

E-mail address: Y-Cheng@popcbr.rockefeller.edu (C.Y. Cheng).
}

Spermatogenesis can be divided into three distinct phases which provide an upward of $150 \times 10^{6}$ spermatozoa per day per man $[1,3]$. The germline stem cells spermatogonia can either self-proliferate (phase 1) or differentiate into primary spermatocytes, which then undergo meiosis and differentiate into secondary spermatocytes and eventually haploid spermatids (phase 2). These cells, in turn, differentiate morphologically and functionally to spermatozoa via spermiogenesis (phase 3), which are released into the tubule lumen at spermiation $[1,3]$. This entire process of germ cell development in the seminiferous epithelium is dependent on temporal and spatial expression of unique sets of genes and proteins. In the rat testis, an epithelial cycle are classified according to the unique germ cell types that associate with Sertoli cells in the epithelium [3,4]. It takes $\sim 58$ days for a single spermatogonium to fully differentiate and develop into 256 spermatozoa. As such, it takes $\sim 4.5$ epithelial cycles for one spermatogonium to differentiate into 256 spermatids. For each stage, at least four germ cell types are present in the epithelium that are organized ( $\sim 12-14$ days duration) can be divided into 14 stages which 


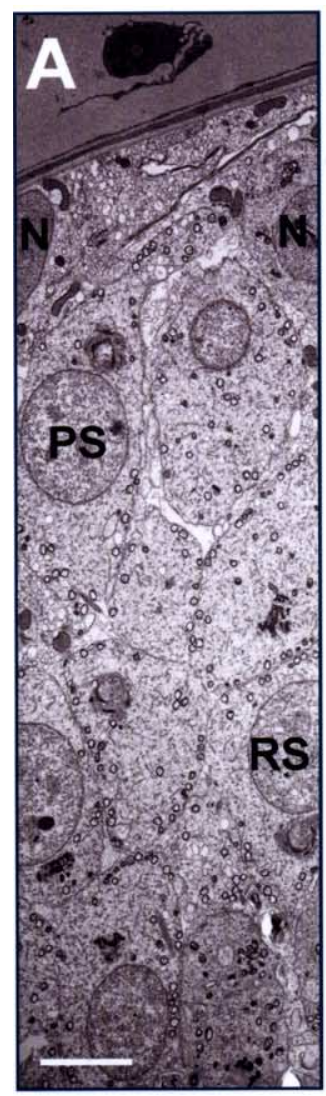

\begin{tabular}{|l|}
\hline Junction types \\
\hline Apical ES \\
- Basal ES \\
AJ \\
GJ \\
- TJ \\
Desmosome- \\
like Junction \\
Hemidesmosome \\
$\nabla$ Apical TBC \\
Basal TBC \\
\hline
\end{tabular}
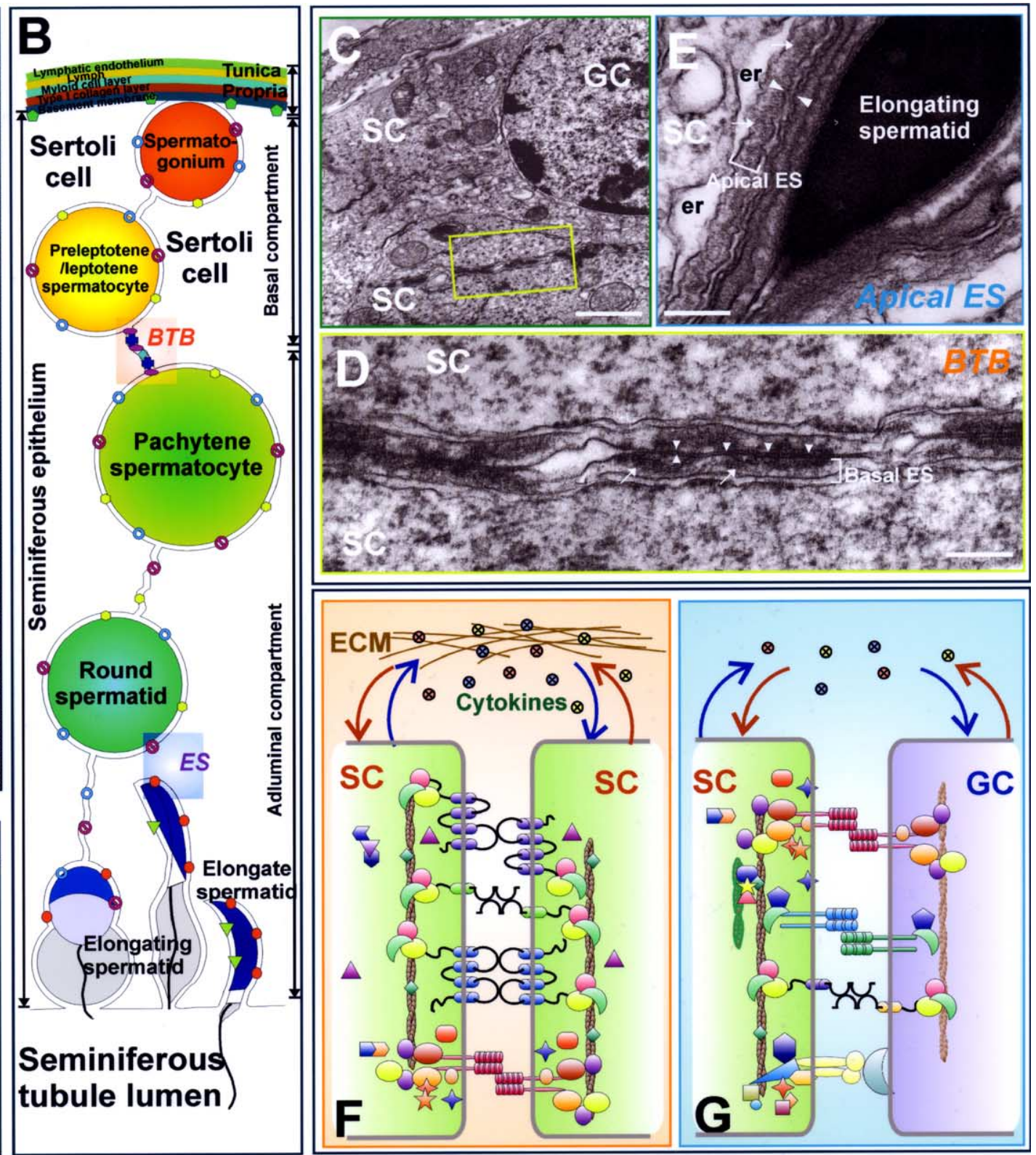

\begin{tabular}{|c|c|c|c|c|c|c|c|c|}
\hline $\begin{array}{l}\text { TJ-integral } \\
\text { membrane }\end{array}$ & $\begin{array}{l}\text { AJ-inte } \\
\text { memb }\end{array}$ & & Adap & ors: & Kinases & hosphatases: & $\begin{array}{l}\text { Signaling } \\
\text { proteins: }\end{array}$ & $\begin{array}{l}\text { Cytoskeletal/ECM } \\
\text { proteins: }\end{array}$ \\
\hline 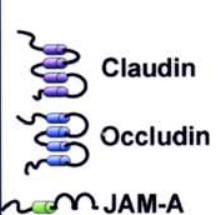 & 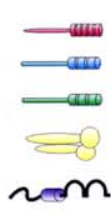 & $\begin{array}{l}\text { Cadherin } \\
\text { Nectin-2 } \\
\text { Nectin-3/-2 } \\
\text { Integrin } \alpha 6 \beta 1 \\
\text { JAM-B }\end{array}$ & $\begin{array}{l}\text { zO-1 } \\
\text { zO-2 } \\
\text { Afadin } \\
\beta \text {-Catenin } \\
\gamma \text {-Catenin }\end{array}$ & $\begin{array}{l}\alpha \text {-Actinin } \\
\text { Paxillin } \\
\text { Vinculin } \\
\text { Axin } \\
\text { WASP }\end{array}$ & $\begin{aligned} & \text { ILK } \\
& \text { FAK } \\
\diamond & \text { c-Src } \\
\text { Ck2 } & \text { PI-3K }\end{aligned}$ & $\begin{array}{l}\text { Fer kinase } \\
\nabla \text { GSK3 } \beta \\
\square \text { Csk } \\
\downarrow \text { MTMR2 }\end{array}$ & $\begin{array}{l}\nabla \text { Cdc42 } \\
\nabla \text { IQGAP-1 } \\
\& \text { Testin }\end{array}$ & 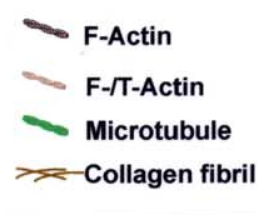 \\
\hline & $\sim m$ & $\begin{array}{l}\text { JAM-C } \\
\text { Laminin- } \gamma 3\end{array}$ & $\begin{array}{l}\alpha \text {-Catenin } \\
\mathbf{p} 120^{\text {tn }}\end{array}$ & $\begin{array}{l}\triangle \text { Zyxin } \\
\text { p130Cas }\end{array}$ & $\triangle \mathrm{PKC}$ & $\rightarrow$ & mulation & Inhibition \\
\hline
\end{tabular}

Fig. 1. Spermatogenesis and cell junctions in the seminiferous epithelium of the mammalian testis (e.g. rats). (A) This is the cross-section of a seminiferous tubule from an adult rat testis showing the intimate relationship between Sertoli cells (N, Sertoli cell nucleus) and germ cells (e.g., pachytene spermatocyte PS, round spermatid RS). (B) Schematic drawing of developing germ cells and their intimate relationship with Sertoli cells during spermatogenesis in the seminiferous epithelium. Also shown is the relative location of different junction types in the epithelium between Sertoli cells as well as between Sertoli and germ cells. Sertoli and germ cells constitue the seminiferous epithelium that is adjacent to the tunica propria. Differentiating germ cells must migrate from the basal to the adluminal compartment, traversing the BTB, which has physically divided the epithelium into the basal and adluminal compartment. (C-E) Electron micrographs of cross sections of seminiferous epithelium illustrating the ultrastructural features of the blood-testis barrier at low (C) and high (D) magnification. The basal ES is characterized by the presence of actin filament bundles (white arrows) sandwiched between the cisternae of endoplasmic reticulum (er), and the 
62 spatially into layers from the base to the lumen of the 63 seminiferous tubule $[3,4]$. Furthermore, spermatogenesis 64 cannot complete without the support of Sertoli cells, which are 65 the only other cell type in the seminiferous epithelium behind 66 the BTB besides germ cells (note: the BTB has physically 67 divided the epithelium into the basal and adluminal 68 compartment, see Fig. 1) [5-7]. Except for the spermatogonia, 69 developing germ cells move progressively toward the lumen 70 [8]. For instance, preleptotene and leptotene spermatocytes 71 that lie at the periphery of the tubule and outside the BTB must 72 traverse the BTB at late stages VIII and early IX of the 73 epithelial cycle [8].

It is conceivable that enormous Sertoli-germ cell interactions take place in the seminiferous epithelium throughout spermatogenesis $[1-4,6,9,10]$. If one views spermatogenesis as a voyage of a germ cell that moves from the basal to the adluminal compartment while developing to a mature spermatozoon, this process involves numerous decision makings and executions. It also requires signalings in and out of germ cells to facilitate this event. Although it is not entirely clear regarding the sequence of these signals, there are at least two sources: external signals from outside the tubule (e.g., via Leydig cells, peritubular myoid cells, and both paracrine and hormonal factors including those from the pituitary gland), and internal crosstalks between germ and Sertoli cells (e.g., integrin-mediated signalings) $[5,6,11,12]$. The phenotypic consequence of these signalings is manifested, at least in part, via the constant remodeling at the Sertoli-Sertoli and Sertoli-germ cell interface where different cell junction types are present $[1,2]$.

The identities of these signals and the details of the remodeling events have become increasingly clear in recent years $[1,2]$. For instance, there is accumulating evidence that illustrates the crucial roles of cytokines pertinent to spermatogenesis and junction restructuring [2]. In this review, we first give an update on the junction complexes that are found in the testis, highlighting how cytokines (e.g., TGF- $\beta 3, \mathrm{TNF} \alpha$ ) can affect junction dynamics and how these signals are being finetuned to allow their regulation of a particular junction type.

\section{The seminiferous epithelium: Sertoli-germ cell junctions and spermatogenesis}

\subsection{Seminiferous epithelium}

The seminiferous epithelium is composed of Sertoli and germ cells. The Sertoli cell is by and large a tall columnar cell extending from the base to the apex of the seminiferous tubule [3]. It is physically reshaped by germ cells to possess many cytoplasic processes because each Sertoli cell is 'nursing' about 30-50 germ cells at different stages of their development at any given time during the epithelial cycle $[13,14]$. In the rat, Sertoli cells cease to proliferate at about day 20 postnatal and the number of these nursing cells determines how many germ cells can be supported and produced via spermatogenesis in the testis [3], illustrating the crucial function of Sertoli cells. For instance, Sertoli cells provide structural support for germ cells and their translocation, create the BTB and define the polarity of the epithelium, secrete numerous biological factors and nutrients for germ cells, and conduct other vital functions pertinent to spermatogenesis (e.g., phagocytosis) $[2,3,14]$.

\subsection{Sertoli-Sertoli and Sertoli-germ cell junctions}

The different junction types that are found in the seminiferous epithelium have recently been reviewed $[1,2]$. Similar to other epithelia or endothelia, virtually all major junction types are found in the testis. Besides the tight junctions that are restricted to the BTB, several anchoring junction types (four are found in most epithelia) are also detected in the testis: (a) adherens junction (including basal and apical ectoplasmic specialization [ES], basal and apical tubulobulbar complex [TBC]); (b) desmosome-like junctions; and (c) hemidesmosomes (for reviews, see $[1,2,10,15])$. ES is a testis-specific, actin-based adherens junction localized at two sites in the seminiferous epithelium: basal and apical compartment (see Fig. 1) [2,9,10,16,17]. Basal ES is limited to BTB and present side-by-side with TJ (Fig. 1). Apical ES is found between elongating/elongate spermatids and Sertoli cells. At least three protein complexes, namely, the cadherin/ catenin, the nectin/afadin, and the integrin/laminin, are known to be ES components $[2,17]$. TBC is another modified AJ type found in the testis $[2,10,18]$. Apical TBC only appears a few days before spermiation in the epithelium at late stage VIII of the epithelial cycle when apical ES begins to disappear whereas basal TBC co-exists with TJ, basal ES, and desmosomal-like junctions at the BTB site. Desmosome-like junctions are present between Sertoli cells and spermatogonia, spermatocytes and round spermatids, being most prominent surrounding pachytene spermatocytes [10]. The BTB is not fully formed until 16-19 days postnatal in the rat testis [3]. Unlike barriers in other organs (e.g., the blood-brain barrier, the blood-retinal barrier) where TJs are localized to the apical region of the epithelium/endothelium, to be

\footnotetext{
Sertoli cell membrane (apposing arrowheads represent the apposing Sertoli cell membranes), which can be found on both sides of the apposing Sertoli cells. Tight junction (TJ) is found between the basal ES, the coexisting TJ and basal ES in turn constitute the BTB. Apical ES is shown in (E) which is typified by the presence of actin filament bundles (white arrowheads) sandwiches between the cisternae of er and Sertoli cell membrane (apposing white arrowheads represent the apposing Sertoli and germ cell membranes). However, this typical feature of ES, in contrast to the basal ES, is restictied only to the Sertoli cell side in apical ES. (F-G) Schematic drawings that illustrate the molecular architecture of the constituent proteins at the BTB (F) and apical ES (G), which include cytokines (e.g., TGF- $\beta 3$ and TNF $\alpha$ ) released from Sertoli and/or germ cells can mediate Sertoli-germ cell crosstalk during spermatogenesis. The protein complexes known to exist at the apical ES site include cadherin/catenin, nectin/afadin, and $\alpha 6 \beta 1$ integrin/laminin $\gamma 3$; whereas occludin/ZO-1, JAM/ZO-1, claudin/ZO-1, cadherin/catenin and nectin/afadin are found at the BTB site. Bar in $\mathrm{E}=10 \mu \mathrm{m}, \mathrm{C}=3 \mu \mathrm{m}, \mathrm{D}=0.25 \mu \mathrm{m}$ and $\mathrm{E}=0.3 \mu \mathrm{m}$, respectively.
} 
followed by AJ, and TJs are furthest away from the ECM; TJs at the BTB lie closest to the basement membrane (a modified form of ECM). Furthermore, BTB is a dynamic structure which must 'open' and 'close' to permit preleptotene/ leptotene spermatocyte transmigration. BTB is a rather complex barrier when compared to other barriers (e.g., gastric-mucosal barrier which is formed by epithelial cells, blood-retinal barrier and blood-brain barrier which are formed by endothelial cells) [19-21] (see Fig. 1). Recent studies have also shown that apical ES is constituted and regulated by proteins that are usually restricted to the focal contact in cell-matrix interface in other epithelia [22]. This hybrid cell-matrix-cell junction type may indeed be essential for rapid junction remodeling to facilitate spermatids orientation and movement at spermiation.

\subsection{Constituent proteins of different junction types in the testis}

\subsubsection{Tight junction (TJ)}

$\mathrm{TJ}$ is the only known example of occluding junction that confers the barrier function of an epithelium or endothelium by restricting the passages of molecules through the intercellular spaces and creates a boundary that defines cell polarity [23]. In the testis, TJ also creates an immunological barrier that sequesters the post-meiotic germ cell antigens from the immune system of the host animals. The currently known TJ integral membrane proteins include JAMs (junctional adhesion molecules), claudins and occludins, which have recently been reviewed [1,2,23,24], as such, only a brief update is provided in this section.

2.3.1.1. JAMs. JAMs are members of a distinct class of cell adhesion molecules typified by the presence of two Ig-like loops in the extracellular domain that are expressed in leukocytes and are localized to tight junctions as integral membrane proteins in epithelial and endothelial cells [25,26]. Since the discovery of JAM-A in 1998 [27], other members, including the more related JAM-B and JAM-C, and the less related JAM4, coxsackie and adenovirus receptor (CAR), and endothelial cell-selective adhesion molecule (ESAM), have recently been added to the list $[25,26,28]$. The presence of JAM-A, B and C in the testis have now been confirmed [29,30]. JAM-A is present at the BTB in the rat testis, co-localizing with ZO-1 [30]. Moreover, JAM-A expression is stage-specific, being highest at IX-XIV, lowest at IV-VI [30]. This stage specificity apparently is related to its possible involvement in BTB dynamics, facilitating the passage of preleptotene/ leptotene spermatocytes across the BTB. Although Jam- $A^{-/}$

mice has been generated, it is not known if the BTB is affected since a morphological examination of the testis has yet to be reported [31]. A recent study on the Jam- $\mathrm{C}^{-/-}$mice have shown that JAM-C is crucial to spermiogenesis since in the viable mutants, mature spermatids are missing [29]. In normal mice, JAM-C is localized to the developing round and elongating spermatids [29]. Interestingly, JAM-B has been localized both to the site of $\mathrm{TJ}$ s at the basal compartment and to the apical ES at the spermatid-Sertoli cell interface in the seminiferous epithelium, outside the BTB [29]. Besides their homophilic interactions amongst JAM-A, B and C, JAM-C can interact with JAM-B heterotypically [32]. Both JAM-B and JAM-C are localized to the heads of spermatids at the apical ES, and this heterophilic association may be important for the Sertoli cell-spermatid adhesion function [29]. Based on currently available data, two roles are suggested for JAMs: in the immune system they are crucial to leukocyte transmigration; and in polarized epithelial and endothelial cells, they seem to take part in organizing TJ and cell polarity [26]. This latter physiological role has been extended to the testis since the cell polarity complex [partitioning-defective (Par) 3/atypical protein kinase $\mathrm{C}(\mathrm{aPKC}) / \mathrm{Cdc} 42$ ] apparently is recruited by JAM-C to facilitate round spermatid polarization and thus differentiation [26]. How JAMs assist preleptotene/leptotene spermatocytes to traverse the BTB similar to neutrophil transmigration across the endothelial TJ-barrier remains to be investigated since germ cells per se, unlike neutrophils or macrophages, are not actively migrating cells. It is possible that JAMs are associated with other motor proteins (e.g., myosin VIIa) and cytoskeletons (e.g., actin, tubulin) that facilitate germ cell movement using the locomotive apparatus in Sertoli cells that provides the necessary protrusive force to guide germ cell movement (for review, see [2]).

JAMs are expressed in multiple epithelia, endothelia, leukocytes and platelets $[25,26]$. The regulation of JAMs in the testis is largely unknown. In the rat testis, when the intratesticular T was suppressed by placing testosterone and estrogen implants subdermally, spermatids (step 8 and beyond) were depleted because of a disruption of the cell adhesion at the ES [30,33-36]. However, the tight junctions at the BTB remained intact which were associated with a significant surge in the levels of JAM-A, occludin and ZO-1 in the epithelium [30]. Indeed, the JAM-A distribution at the BTB site in the basal compartment of the seminiferous epithelium was significantly induced and intensified, becoming a thickened and prominent ring surrounding the entire tubule [30]. It is apparent that a depletion of androgen in the testis triggers a novel mechanism that leads to two distinctive events: germ cell loss and a reinforced BTB [30]. Another model using Adjudin to induce germ cell sloughing from the epithelium in adult rat testes has yield similar results in which JAM-A expression was induced at the time of germ cell depletion (unpublished observations). Although the compounds that were used to trigger the changes in the epithelium are different in these two models, namely androgen suppression and Adjudin, the signaling events (e.g., both treatments activate the integrin/focal adhesion kinase signaling pathway) and the phenotypic outcome (e.g., germ cell loss from the epithelium and a reinforced BTB) are similar [36,37]. This seemingly suggests that JAM-A is 
regulated, at least in part, by a mechanism downstream of lowered intratesticular $\mathrm{T}$ level that triggers germ cell sloughing from the epithelium. It is not known if cytokines are the upstream regulators of JAMs. An earlier report has shown that TNF and IFN- $\gamma$ treatment of human umbilical vein endothelial cells can reduce cell surface expression of JAM-A, but these cytokines have no effects on the rate of transmigration of neutrophils [38].

\subsubsection{Claudins. The claudin superfamily of TJ integral} membrane proteins consists of at least 24 members with $\mathrm{Mr}$ ranging between 20 and $27 \mathrm{kDa}[39,40]$. Claudins have a unique expression profile in a tissue [39]. For instance, claudin-1 and claudin-11 are expressed in the testis, mostly restricted to Sertoli cells, and the brain, whereas more than 10 claudin members are expressed in the kidney [39]. In the testis, the expression of claudin- $3,-4,-5,-7,-8$ has also been reported $[2,41]$. Claudin-11, also known as oligodendrocytespecific protein (OSP), is the best studied claudin in the testis [42-46]. Cld-11 $1^{-1-}$ mice were sterile and were associated with the absence of $\mathrm{TJ}$ strands in the seminiferous epithelium and in the myelin sheath in the brain [46]. Claudin-11 is known to be up-regulated by androgens $[42,47]$ and downregulated by TGF- $\beta 3$ [44] in Sertoli cells cultured in vitro. Claudin-11 expression is high from postnatal days 10-16 in the rat testis corresponding to the maturation of BTB [43]. Anti-androgen, such as flutamide, can also inhibit the expression of claudin-11 in prepubertal rat testes [42]. Claudin-11 is also important for hearing function since Cld $11^{-1-}$ mice lacking TJ in the basal cells of stria vascularis in cochlea failed to compartmentalize the endolymph and suppressed electrical potentials [48].

TJ strands in the intercellular junction are not a static but dynamic structure. A recent study by real-time imaging to examine the behavior of exogenously expressed claudin-1 in mouse L fibroblasts showed that the paired claudin strands underwent constant and dynamic reorganization while maintaining the structural integrity of the entire TJ network [49]. Internalization of claudin-3 was also observed via endocytosis in confluent epithelial cells, after it was dissociated from other TJ components, such as JAM, occludin and ZO-1 [50]. This dynamic nature of claudins, plausibly applicable to other TJ constituent proteins, is not entirely unexpected since $\mathrm{TJ}$ barriers must undergo conformational changes to accommodate paracellular transport of substances, such as during food adsorption in the small intestine. For the BTB, it has to be 'opened (or 'dissolved' ?) and then 'closed' (or 'regenerated' ?) frequently to facilitate germ cell passage while maintaining the barrier function during the epithelial cycle. It is likely that such reorganization of claudin strands, possibly also of occludin- and JAM-constituted TJ strands, are occurring at the BTB. The uncoupling of TJ proteins may indeed be a prerequisite for the dual roles played by the BTB during its restructuring to permit germ cell passage while maintaining the barrier function simultaneously.
2.3.1.3. Occludin. Occludin is the first TJ integral membrane protein found in epithelia [51] and is the most studied in this category. Occludin is known to be regulated by cytokines in the testis (e.g., TGF- $\beta 2$, TGF- $\beta 3$ ) [44,52]. Other signaling events are recently shown to engage in its regulation as well. In the androgen-suppressed rat testes to induce germ cell loss from the epithelium, occludin expression, similar to JAM-A, is significantly induced, resulting in prominent staining at the BTB when Sertoligerm cell adhesion function was compromised [30]. This also reinforces the notion that the regulation of $\mathrm{TJ}$ proteins is essentially different from that of AJ proteins in the rat testis. Occludin is also regulated, at least in part, by ubiquitination [53]. Itch (an E3 ubiquitin ligase) and UBC4 (an ubiquitinconjugating enzyme) are reciprocally regulated versus occludin during Sertoli cell TJ assembly or disassembly, and ubiquitin-conjugated and Itch-conjugated occludin are detected when the dibutyryl-cAMP-induced degradation of occludin is blocked by a proteasome inhibitor MG-132 [53]. Other cytokines, such as TNF $\alpha$, IL- $1 \beta$, IFN- $\gamma$, can also affect occludin expression and its distribution at TJs in multiple epithelia and endothelia [54-56]. It is not known if these cytokines can exert any effect on occludin expression or its cellular distribution at the BTB. But TNF $\alpha$ has been shown to perturb TJ-barrier function in Sertoli cell cultures [57] and can cause germ cell exfoliation in the rat testis after its systemic administration [58]. Recent studies have shown that TNF and IFN- $\gamma$ can indeed regulate occludin transcription by diminishing its promoter activity [55].

\subsubsection{Anchoring junction}

2.3.2.1. The cadherin/catenin protein complex. Cadherins are transmembrane glycoproteins that mediate calciumdependent cell-cell adhesion in multiple epithelia including the seminiferous epithelium in the testis $[59,60]$. The cadherin superfamily consists of over 80 members that fall into at least six subfamilies, which include (i) the type I classical cadherins (e.g., E-cadherin, N-cadherin, P-cadherin) and its highly related; (ii) type II classical cadherins (e.g., VE-cadherin); (iii) desmosomal cadherins (desmocollins and desmogleins); (iv) protocadherins; (v) sevenpass transmembrane cadherins (Flamingo); and (vi) Fat-like cadherins [59-62]. Type I classical cadherins are the best studied cadherins in multiple tissues including the testis. Besides the classical cadherins, the presence of other subfamilies in the testis, such as protocadherins, Fat and Flamingo, has also been detected by RT-PCR [63], but their function in the seminiferous epithelium are less known. During development, the expression of different cadherins is highly dynamic [64] and this seems to be applicable to the testis as well since the expression profile of cadherins varies with the age and cell types in the rat testis where at least 24 cadherins are known to be present [63]. For instance, Ncadherin is predominantly localized to the basal ES and the periphery of the seminiferous tubules with restricted and stage-specific localization at the apical ES [30,65-69], 
whereas E-cadherin is relatively more abundant in germ cells $[63,66]$. A smaller amount of $\mathrm{N}$-cadherin in the testis appears also to be a component of desmosomal-like junctions which is a hybrid junction type of desmosome and gap junctions [65,67]. Indeed, $\mathrm{N}$-cadherin has been shown to link to both actin microfilament and microtubules in the testis [66]. A recent report has also illustrated that protocadherin $\alpha 3$ is associated with spermatids at the acrosomal area, intercellular bridge as well as flagellum, distinct from the distribution of classical cadherins [70].

Classical cadherin-based protein complex comprising of the transmembrane protein cadherins and intracellular adaptor catenins is a well defined focal point of cell adhesion and signaling [59,71]. $\beta$-Catenin and $\gamma$-catenin connects cadherins to $\alpha$-catenin and $\alpha$-actinin, which are two putative actin binding proteins [72]. Phosphorylation of $\beta$-catenin can in turn regulate the integrity of the cadherin/ catenin complex [73]. In both Adjudin- and androgen suppression-induced germ cell loss models, the event of germ cell loss is facilitated by the dissociation of $\mathrm{N}$ cadherin from $\beta$-catenin $[30,35,68]$. Indeed, increased tyrosine phosphorylation of $\beta$-catenin was detected at the time of germ cell depletion in these models [30]. Kinases and phosphatases are also known to regulate cadherin/ catenin association $[35,74,75]$. For instance, myotubularinrelated protein 2 (MTMR2), a lipid phosphoinositide phosphatase, was shown to interact with the kinase c-Src [35] and $\mathrm{c}-\mathrm{Src}$ in turn associates with the $\mathrm{N}$-cadherin/ $\beta$ catenin complex [74]. This illustrates a novel regulatory mechanism may be in place in the testis regarding the cadherin/catenin-mediated cell adhesion function in which MTMR2 and c-Src regulate the phosphorylation status of the cadherin/catenin, which in turn determines its cell adhesive function. More recent studies have shown that the $\mathrm{N}$-cadherin/ $\beta$-catenin adhesion unit can also be regulated by the equilibrium between IQGAP-1 (IQ motif containing GTPase activating protein, an effector of Cdc42 GTPase) and $\mathrm{Cdc} 42$ in Sertoli-germ cell AJ [76]. For instance, using $\mathrm{a} \mathrm{Ca}^{2+}$ switch model, it has been demonstrated that at low $\mathrm{Ca}^{2+}$ level, IQGAP-1 is released from Cdc42, and interacts with $\beta$-catenin instead, causing the dissociation of $\beta$ catenin from $\mathrm{N}$-cadherin, and germ cell depletion from Sertoli cells [76].

E-Cadherin is also a tumor suppressor which is downregulated while $\mathrm{N}$-cadherin is up-regulated during epithelial tumor progression $[64,77,78]$. This 'cadherin switch' further illustrates the unique yet pivotal role of each cadherin in cell adhesion and cell motility. It is not clear if such dynamic switch-over between different cadherins occur during germ cell movement in the seminiferous epithelium. However, $\mathrm{N}$-cadherin can become highly expressed in the testis of Adjudin treated rats during germ cell loss from the epithelium [66-68]. N-cadherin is also up-regulated in androgen suppressed rat testes during germ cell loss [30,35]. Yet such a surge in N-cadherin cannot rescue germ cell loss from the epithelium since a loss of association between $\mathrm{N}$ - cadherin and $\beta$-catenin was detected at the time of germ cell sloughing in both models $[30,35]$. It seems that such an induction of cadherins reinforces the BTB integrity since Ncadherin is also a component protein of the BTB in the rat testis.

2.3.2.2. The nectin/afadin/ponsin/ADIP complex. The nectin/afadin/ponsin complex is another actin-based cell adhesion protein complex that plays a crucial role in the testis during spermatogenesis. It confers Sertoli-germ cell adhesion function particularly for elongating/elongate spermatids $[1,2,68,79]$. Four nectins (nectin-1, $-2,-3$, and 4) have been identified thus far, all of which are expressed in the testis with nectin-2 and nectin-3 being the highly expressed [2,80-82]. Nectin-3 is restricted exclusively to elongating/elongate spermatids which can heterotypically interacting with nectin- 2 on the Sertoli cell side $[68,83]$. Spermatozoa from nectin- $2^{-1-}$ mice were morphologically aberrant and functionally impotent [83-85]. Since nectins are capable of activating Cdc42 via c-Src and a Cdc42 GEF (GDP/GTP exchange factor) [86], or activating Rac, thus recruiting the polarity complex Par3/aPKC/Par6 to the apical ES site [87], the absence of nectin-3 may also lead to malfunctioning of spermatid polarization, similar to Jam$C^{-1-}$ mice [29]. Nectins are known to initiate cell-cell contacts by recruiting cadherin and JAM-A to establish functional $\mathrm{AJ}$ and $\mathrm{TJ}$ in epithelial cells [79,87-89]. It is likely that nectin-2/-3 and JAM-B/-C can also interact with each other since they are all localized to the elongating/ elongate spermatids at the apical ES site, which should be investigated in future studies. In the Adjudin-induced germ cell loss model, it was found that the nectin-3/afadin interaction became severely weakened before any obvious reduction in their protein levels was detected [68], illustrating this cell adhesion unit must be compromised to facilitate spermatid loss (Table 1).

Besides afadin and ponsin, cytoplasmic adaptors that link nectin to the actin-based cytoskeleton [79], a new adaptor protein ADIP (afadin DIL domain-interacting protein) has recently been localized to $\mathrm{AJ}$ sites that interacts with both $\alpha$ actinin and afadin, providing additional cytoplasmic link between nectin- and cadherin-based cell adhesion units [90,91]. ADIP is highly expressed in the mouse testis [90]. Another possible linker that binds to both afadin and $\alpha$ actinin is LMO7 (LIM domain only 7), however, its presence in the rat testis failed to be confirmed by immunoblot analysis [92].

Nectin-like (Necl) molecules are similar to nectins, but do not bind to afadins $[87,88]$. This group of calciumindependent cell adhesion molecules consists of five members, capable of homo- or heterophilic interactions with nectins, and are important cell-cell adhesion molecules in various tissues $[87,88]$. At least $\mathrm{Necl} 2$ has been shown to be highly expressed in the rat testis [93]. It will be important to explore the significance of Necls in the testis, which is likely to involve in Sertoli-germ cell adhesion function. 
Table 1

Cytokine-mediated regulation of junction component proteins in epithelia including the testis

\begin{tabular}{|c|c|c|c|}
\hline Junction component & Protein & $\begin{array}{l}\text { Cytokine/hormone that modulates the steady-state } \\
\text { mRNA/protein level }(+/-) \text { or protein distribution pattern } \\
\text { (d) of the target junction protein }\end{array}$ & Selected references \\
\hline \multirow[t]{3}{*}{ TJ-integral membrane } & JAM-A & $\mathrm{TNF}(\mathrm{d}), \mathrm{IFN}-\gamma(\mathrm{d}), \mathrm{T} \downarrow(+)$ & {$[30,38]$} \\
\hline & Occludin & $\begin{array}{l}\text { TGF- } \beta 3(-), \text { HGF }(-/ d), \operatorname{TNF}(-/ d), \operatorname{IFN}-\gamma(-/ d), \text { VEGF } \\
(-/ d \text {, inhibited by ANP), IL-1 } \beta(-/ d), \operatorname{IL}-4(-), \operatorname{IL}-13(-), \operatorname{MCP}-1(-), \text { T } \downarrow(+)\end{array}$ & {$[44,52,54-56,223-225]$} \\
\hline & Claudin & TGF- $\beta 3(-)$, TNF $(-)$, FSH/cAMP $(-)$ & {$[43,44]$} \\
\hline \multirow[t]{4}{*}{ AJ-integral membrane } & N-Cadherin & $\operatorname{HGF}(+), \operatorname{EGF}(+)$, TGF- $\beta(+/ d), T(+), T \downarrow(+), \operatorname{IL}-6(-)$ & {$[30,66,78]$} \\
\hline & E-Cadherin & TGF- $\beta(-/ d), T(+)$ & {$[52,66,68]$} \\
\hline & Nectin-3 & TGF- $\beta 3(-/ d)$ & {$[52,68]$} \\
\hline & Integrin- $\beta 1$ & TGF- $\beta(+), T \downarrow(+)$, & {$[30,226]$} \\
\hline \multirow[t]{4}{*}{ Adaptor } & $\mathrm{ZO}-1$ & TGF- $\beta$ (d), IL-4 (-), IL-13 (-), T $\downarrow(+)$ & {$[30,225]$} \\
\hline & Afadin & TGF- $\beta 3(-/ d)$ & [68] \\
\hline & $\beta$-Catenin & TGF- $\beta(d), T \downarrow(+)$ & {$[30,139,227]$} \\
\hline & $\alpha$-Catenin & TGF- $\beta(d), T \downarrow(+)$ & {$[30,139,227]$} \\
\hline
\end{tabular}

$\mathrm{T} \downarrow$, suppression of intratesticular testosterone level with the use of testosterone (T) and estradiol implants; + , stimulation; - , inhibition. Protein distribution pattern was assessed by either immunofluorescent microscopy or immunohistochemistry using testicular cells cultured in vitro or seminiferous epithelium in vivo.

\subsubsection{The integrin/laminin complex. The integrin/lami-} nin protein complex has recently been identified at the apical ES which confers Sertoli-germ cell adhesion and provides a new platform regarding how these two cell types interact with each other and coordinate spermatogenesis [37,94]. Integrin-based protein complexes are usually found at the cell-matrix junctions, such as hemidesmosomes or focal adhesion, which further connects to the intermediate filament or actin bundles, with integrin also capable of serving as a cell receptor for the ECM $[95,96]$. Interestingly, the junctions between Sertoli and germ cells are not simple cell-cell junction types; rather, they are a hybrid of both cell-cell and cell-matrix junction types, probably to facilitate rapid junction turnover and germ cell migration during spermatogenesis [22]. Several recent reviews on the role of integrins and ECM in the testis are available, thus this information is not discussed herein [22,97].

\section{Cytokines are key regulators of junction dynamics in the testis}

Cytokines are regulatory peptides (usually $\leq 30 \mathrm{kDa}$ in size) produced virtually by every nucleated cells in mammals and have pleiotropic actions on cell physiology as an autocrine or paracrine factor [98]. In the testis, Sertoli and germ cells produce a number of cytokines, including members of the TGF- $\beta$ superfamily (e.g., TGF- $\beta$ s, activins, inhibins), platelet-derived growth factor (PDGF), interleukins (e.g., IL-1, IL-6, IL-11), tumor necrosis factor (e.g., $\mathrm{TNF} \alpha$, Fas ligand), interferons (e.g., IFN- $\alpha$, IFN- $\gamma$ ), fibroblast growth factor (FGF), nerve growth factor (NGF), and stem cell factor (or steel factor) (for reviews, see $[1,2,11,99,100])$ (see also Table 2). These cytokines likely mediate crosstalk between Sertoli and germ cells to facilitate germ cell movement across the seminiferous epithelium and other cellular events in the epithelium during the epithelial cycle such as germ cell differentiation. Herein, we critically evaluate two best studied cytokines, namely TNF $\alpha$ and TGF$\beta 3$, regarding their significance in spermatogenesis in the testis and briefly summarize the action of other cytokines.

\subsection{TNF}

TNF, also known as TNF $\alpha$ or cachectin, is synthesized as a $26 \mathrm{kDa}$ type II transmembrane prepeptide (pro-TNF), which is subsequently activated by proteolytic cleavage to release the C-terminal $17 \mathrm{kDa}$ mature protein by the TNFconverting enzyme (TACE). The mature protein is formed by aggregates creating a homotrimer that can bind to two types of receptors: TNFR1 and TNFR2 [101,102]. The major source of TNF $\alpha$ in mammalian body is immune cells such as macrophage and monocytes, but TNF $\alpha$ is also produced by other non-immune cells including astrocytes, keratinotytes, Sertoli cells and germ cells [57,101]. TNF signaling is mediated mainly through TNFR1, which has distinct domains that facilitate the recruitment of other intracellular adaptors to activate signaling pathways. The net result of such activation can modulate apoptosis, inflammation and cell proliferation $[101,103]$. These adaptors include TNFR1-associated death domain protein (TRADD) which can recruit Fas-associated death domain protein (FADD), TNF receptor associated factor-2 (TRAF-2), or receptorinteracting protein (RIP), to induce the caspase-mediated apoptosis, activate transcription factors (e.g., c-jun, c-fos, ATF-2) via MAPK (ERK, JNK and p38), or activate nuclear factor kappa $\mathrm{B}(\mathrm{NF \kappa B})$ through inhibitor of NFкB kinase (IKK), respectively [101-103]. A TNFR1 scaffolding protein called TGFR-associated ubiquitous scaffolding and signaling protein (TRUSS) has recently been cloned and characterized [104]. The expression of TRUSS is enriched in heart, liver and testes, it is also known to interact with TRADD, TRAF-2 and IKK [104]. In addition to these complex signaling networks that can be activated down- 
Table 2

Cytokines and their functions in the testis

\begin{tabular}{|c|c|c|c|c|c|}
\hline Group & Cytokine & KO mice & Cellular expression & Function in the testis & References \\
\hline \multirow[t]{6}{*}{ TGF- $\beta$} & TGF- $\beta 1$ & Perinatal/neonatal lethal & Sertoli, Leydig, germ, myoid cells & Testicular development & {$[109,112,119,123]$} \\
\hline & TGF- $\beta 2$ & Perinatal lethal & Sertoli, Leydig and germ cells & Testicular development & \\
\hline & TGF- $\beta 3$ & Perinatal lethal & Sertoli and germ cells & Junction dynamics & \\
\hline & Activin/inhibin $\beta A$ & Perinatal lethal & Sertoli and peritubular cells & Regulate FSH production, testicular development & {$[109,228]$} \\
\hline & Activin/inhibin $\beta B$ & $\begin{array}{l}\text { Viable/reproductive } \\
\text { abnormality (female) }\end{array}$ & Sertoli cells, germ cells & & \\
\hline & BMP-4 & $\begin{array}{l}\text { Embryonic lethal }(-/-) / \\
\text { lowered fecundity }(+/-)\end{array}$ & $\begin{array}{l}\text { Pachytene spermatocytes, } \\
\text { Sertoli cells (early postnatal) }\end{array}$ & Maintain spermatogenesis; spermatogonia differentiation & {$[109,229-231]$} \\
\hline \multirow[t]{3}{*}{ TNF } & $\mathrm{TNF} \alpha$ & Viable/fertile & Sertoli, germ cells & Repress steroidogenesis, disrupt $\mathrm{TJ}$, inhibit GC apoptosis & {$[57,106-108,218,232]$} \\
\hline & FasL & Viable & $\begin{array}{l}\text { Spermatocytes/spermatids; } \\
\text { Sertoli cell (?) }\end{array}$ & Induce apoptosis, preserve immune-privilege & {$[233-235]$} \\
\hline & TRAIL & Viable/fertile & Germ, Leydig cells & GC apoptosis & {$[236,237]$} \\
\hline \multirow[t]{6}{*}{ Growth factors } & EGF & Viable/fertile & Sertoli, germ cells & Maintain spermatogenesis; stimulate steroidogenesis; & [238-240] \\
\hline & FGF4 & Embryonic lethal & Sertoli cells & Enhance spermatogenesis & [241-243] \\
\hline & HGF & Embryonic lethal & Spermatozoa, myoid cells & Initiate sperm motility, induce testicular cord formation & [244-246] \\
\hline & MIF & Viable/fertile & Leydig cells & Leydig-Sertoli cell paracrine mediator/inhibit & {$[247,248]$} \\
\hline & SCF & $\begin{array}{l}\text { Perinatal lethal }(-/-) \text {, } \\
\text { sterile }(+/-)\end{array}$ & $\begin{array}{l}\text { Sertoli cells (c-Kit receptor } \\
\text { on differentiating spermatogonia) }\end{array}$ & $\begin{array}{l}\text { Spermtogenesis; Sertoli cell-spermatogonia adhesion } \\
\text { (membrane bound form) }\end{array}$ & {$[11,249,250]$} \\
\hline & VEGF (A) & Embryonic lethal $(+/-)$ & $\begin{array}{l}\text { Sertoli cells (receptor on germ cells), } \\
\text { Leydig cells }\end{array}$ & Spermatogonial proliferation, spermiogenesis & {$[251-253]$} \\
\hline \multirow[t]{2}{*}{ Interleukin/interferon } & IL- $1 \alpha /-1 \beta$ & Viable/lowered fecundity & Sertoli cells, spermatocytes, spermatids & Inhibit steroidogenesis, Regulate Sertoli secretion & {$[254,255]$} \\
\hline & IFN- $\gamma$ & Viable/fertile & Spermatogonia, interstitium & Inhibit steroidogenesis, stimulate FasL expression & {$[256,257]$} \\
\hline
\end{tabular}

Abbreviation: bone morphogenetic protein (BMP), epidermal growth factor (EGF), fibroblast growth factor (FGF), hepatocyte growth factor (HGF, or scatter factor, SF), interferon (IFN), interleukin (IL), macrophage migration inhibitory factor (MIF), Stem cell factor (SCF, or Steel factor, SLF), transforming growth factor $\beta$ (TGF- $\beta$ ), tumor necrosis factor $\alpha$ (TNF- $\alpha$ ), tumor necrosis factor- $\alpha$-related apoptosisinducing ligand (TRAIL), vascular endothelial growth factor (VEGF). 
stream of TNF, at least 19 ligands and more than 20 receptors have been identified in the TNF superfamily [103], which can mediate an array of physiological processes and diseases [103]. It has been known that TNF can disrupt TJ integrity in multiple epithelial cells. As aforementioned, TNF down-regulates occludin expression through its promoter activity [55] or reduces JAM-A distribution on the vascular endothelial cell surface [38]. TNF level is also elevated in Crohn's disease, a chronic granulomatous inflammatory disease that affects the gastrointestinal tract, which is manifested by impaired intestinal barrier function with leaky TJs [105]. With the exception of TNF and Fas ligand (FasL), the roles of other members of TNF superfamily in the testis remain elusive.

In the testis, $\mathrm{TNF} \alpha$ has been shown to play a role in regulating germ cell apoptosis, junction remodeling and Leydig cell steroidogenesis $[57,106,107]$. For instance, it is known that $\mathrm{TNF} \alpha$ represses the expression of steroidogenicenzyme genes in Leydig cells through an activation of $\mathrm{NF \kappa B}$, which can in turn inhibit the transactivation of orphan nuclear receptors [106]. Intratesticular injection of TNF in normal and hypophysectomized rats has also demonstrated its suppressive effect on testosterone production in vivo [108]. Chronic infusion of TNF caused germ cell (in particular spermatocytes and spermatids) depletion from the epithelium, a loss of testis weight and a plunge in testosterone level [58]. It remains unknown regarding the mechanism(s) by which $\mathrm{TNF} \alpha$ utilized to induce these changes, but this could involve a suppression of Leydig cells steroidogenesis, or an inhibition of Sertoli cell TJ protein production at the BTB, or via its direct effect on germ cells. Other recent studies have shown that $\mathrm{TNF} \alpha$ can perturb the TJ-permeability barrier in cultured Sertoli cells dosedependently and reversibly since the disrupted TJ-barrier can be resealed upon the removal of the cytokine [57]. This inhibitory effect of TNF $\alpha$ on Sertoli cell TJ function is likely mediated via an induced production of collagen $\alpha 3$ (IV), matrix metalloprotease (MMP)-9 and tissue inhibitor of metalloprotease (TIMP)-1 which collectively affect the homeostasis of ECM, thereby altering the association of the Sertoli cell epithelium with the basement membrane and perturbing the TJ-barrier [57]. Also, TNF $\alpha$ can activate the integrin/integrin linked kinase (ILK)/glycogen synthase kinase (GSK) $\beta-3 /$ p130 Cas/JNK signaling pathway which also contribute to changes in the TJ-protein expression and/ or distribution at the BTB $[22,57,97]$.

\section{2. $T G F-\beta$}

The TGF- $\beta$ superfamily comprises of TGF- $\beta$ s, activins, inhibins, bone morphogenetic proteins (BMPs), growth differentiation factors (GDFs), Müllerian-inhibiting substance (MIS) and others, totaling more than 35 members [109]. TGF- $\beta$ superfamily proteins are crucial in the regulation of a variety of biological processes, including cell proliferation, differentiation, apoptosis, and tissue remodeling [110]. Some members, like activins and inhibins, were initially identified in the male gonad for their ability to regulate the pituitary follicle stimulating hormone (FSH) production [11]. MIS is known for its role in sexual differentiation causing the regression of the Müllerian ducts in the male [111]. The functions of TGF$\beta$ superfamily proteins in reproduction have been recently reviewed [109,112] hence we only focus on regulation of junction restructuring by TGF- $\beta$ s herein, which is elaborated in Section 4. Table 2 summarizes other cytokines that are known regulators of junction dynamics.

\subsection{Cytokines working in concert with other ECM proteins to regulate junction dynamics}

Recent reviews have summarized how cytokines regulate the homeostasis of proteases and their inhibitors, and ECM proteins to coordinate spermatogenesis [2,22,97]. It is not at all surprising that these molecules are working in concert since their production, activation, and termination are all interdependent and connected. Their homeostasis and regulation are essential to almost all biological processes. In the testis, for instance, when the BTB is disrupted by cadmium, TGF- $\beta 3 / \mathrm{p} 38$ MAPK signaling is activated to down-regulate the steady-state of TJ and AJ protein levels that leads to the breakdown of both junctions and germ cell exfoliation [44,52,113]. Proteases (e.g., cathepsin L) and protease inhibitors (e.g., $\alpha_{2}$-macroglobulin) are induced to coordinate the junction restructuring event [52]. Using a p38 MAPK inhibitor SB202190, the damage to the BTB and the plunge of $\mathrm{TJ}$ and $\mathrm{AJ}$ proteins induced by $\mathrm{CdCl}_{2}$ can be delayed but it cannot prevent the overexpression of protease inhibitor $\alpha_{2}$-MG [52]. Further study revealed that $\alpha_{2}-\mathrm{MG}$ production is regulated by JNK signaling pathway in the testis, independent of the p38 MAPK pathway [114]. This yin and yang relation of protease and protease inhibitor regulation that utilizes distinct signaling pathways, and their connection with cytokines (e.g., TGF- $\beta 3$ ) have illustrated that the testis is equipped with some delicate regulatory mechanisms to orchestrate junction restructuring at spermatogenesis.

\section{TGF- $\beta 3$ as a junction regulator-versatility realized through selectivity}

\subsection{Signaling conduits and versatile players in biological processes}

TGF- $\beta$ s $(\beta 1, \beta 2$ and $\beta 3)$ are key regulators in a plethora of biological processes (for reviews, see [110,115-120]). These cytokines, when activated by releasing from the latency-associated proteins (LAPs), can bind to their receptors-first to the type II receptor, T $\beta$ RII, which then recruits the type I receptor, T $\beta$ RI (or ALT5, activin-like kinase) - although TGF- $\beta 2$ requires binding of the two
646 
receptors more or less at the same time and the assistance from the type III receptor, betaglycan. The binding of the cytokine to type I and type II receptors initiates a series of phosphorylation mediated activation-autophosphorylation of T $\beta$ RII and T $\beta$ RI phosphorylation by T $\beta$ RII-and triggers consequent intracellular signaling events (the canonical Smad-mediated signalings and Smad-independent pathways). Despite their structural similarities and shared signaling mechanisms, the three TGF- $\beta$ s are spatiotemporally expressed and play non-redundant roles, particularly under in vivo conditions. This in part is attributed to their unique promoter sequences [121]. For instance, in the mouse testis, expression of TGF- $\beta 1$ and TGF- $\beta 2$ are much higher in embryonic and early postnatal stages, and TGF- $\beta 3$ becomes the highest expressed among the three isoforms in adulthood [122]. Similarly, in postnatal day 5 to day 60 rats, TGF- $\beta 1$ and TGF- $\beta 2$ expression are predominant in immature testes, which decrease at the onset of puberty; whereas TGF- $\beta 3$ expression is most abundant at the pubertal stage, coinciding with the initiation of spermatogenesis [123]. These thus illustrate TGF- $\beta$ s have unique roles in distinct phases of testicular development: TGF- $\beta 1$ and TGF$\beta 2$ are important for the development while TGF- $\beta 3$ takes the center stage during spermatogenesis. Herein, we summarize the TGF- $\beta$-mediated signaling conduits, focusing on their regulation of junction remodeling.

\subsubsection{Smad-mediated signaling}

The smad-mediated TGF- $\beta$ signaling pathways have been extensively characterized and recently reviewed $[110,116,124,125]$. Among the 8 Smad proteins (Smad18), receptor-regulated R-Smad ( $\operatorname{Smad} 2$ and $\mathrm{Smad} 3)$, common-partner Co-Smad (Smad4) and inhibitory I-Smad (Smad 7) are involved in TGF- $\beta / T \beta R I I / T \beta R I$ signaling. However, many of these Smad proteins have not been subjected to rigorous investigation in the testis. In the testis, the expression of Smad2 and Smad3 are developmentally regulated and stage-specific: being more prominent in prepubertal than in sexually mature rats, and at the lowest levels at stages VII-VIII of the epithelial cycle in adult rats [126]. Expression of Smad3, 4, 6 and 7 are also detected in embryonic mouse testes [127]. It is not surprising that Smad proteins are highly expressed in younger animals since TGF$\beta$ superfamily members are essential for development. TGF$\beta 1$ and TGF- $\beta 2$ may be more important in the testis at the early stages through Smad-mediated signaling pathways. Yet the regulation and maintenance of spermatogenesis by TGF- $\beta 3$ in adult testes is likely mediated via Smadindependent signalings, such as TJ and BTB dynamics [68]. For instance, TGF- $\beta 3$ activates ERK without activation of Smad2 and Smad3 in the Adjudin-induced germ cell loss model [68].

\subsubsection{MAPK-mediated signaling}

There are accumulating evidence in the literature regarding Smad-independent TGF- $\beta$ signalings that regulate diverse biological function, which has recently been reviewed $[115,116,118,128]$. Amongst these, the best studied is the MAPK signalings [129-131]. For instance, TGF- $\beta$ is capable of activating all three MAPK pathways $[115,118,125]$. In the testis, all three pathways have been implicated in the regulation of junction dynamics pertinent to spermatogenesis. First, JNK pathway is involved in TNF- $\alpha$-induced TJ restructuring and $\alpha_{2}-\mathrm{MG}$ regulation [57,114]. Second, ERK pathway can be activated via either integrin or TGF- $\beta 3$, which can in turn regulate AJ dynamics [36,37,68]. Third, p38 MAPK is responsible for TGF- $\beta 3$-activated $\mathrm{TJ}$ and $\mathrm{AJ}$ restructuring [52,113,132]. Nonetheless, little is known about the expression and distribution of MAPKs and their upstream kinases in the testis. ERK1/2 and p-ERK1/2 have been localized to the elongate spermatids at the apical ES/TBC site in the epithelium at stages VII-VIII [68,133], illustrating its role in spermiation. ERK $1 / 2$ is also detected at the basal compartment of the epithelium [133]. Indeed, when induced by Adjudin, p-ERK1/2 is activated at the site of apical ES in depleting elongate/elongating spermatids in tubules other than stages VII-VIII, probably facilitating germ cell exfoliation [68].

The complexity of TGF- $\beta$-mediated signaling pathways is manifested by the presence of multiple intracellular interacting points. Recent studies have identified different interacting proteins with TGF- $\beta$ receptors, illustrating these proteins may play a role in selecting the downstream signaling events. For example, occludin is known to associate with T $\beta$ RI and as such, TGF- $\beta$ can efficiently regulate TJ disruption during epithelial-mesenchymal transition (EMT) [134]. Indeed, the proximity of TGF- $\beta$ receptors with TJ proteins has created an efficient regulatory mechanism where TGF- $\beta$-induced TJ dissolution is mediated through the cell polarity complex. Upon activation by TGF- $\beta$, T $\beta$ RII is recruited to the $\mathrm{T} \beta \mathrm{RI} / \mathrm{occludin} / \mathrm{Par} 6$ complex, thereby phosphorylating Par6, this in turn stimulates Par6 which binds to Smurf1 (an E3 ubiquitin ligase), and causing degradation of RhoA that leads to TJ disassembly [135,136]. Although it has not yet been confirmed for T $\beta$ RII, proteins that associate with type II receptor of BMP have recently been identified, which include MAPK, PKC, and cytoskeleton tubulin $\beta 5$ [137]. These proteins associate not only with the kinase domain of the receptor but also its C-terminus [137], illustrating receptors of the TGF- $\beta$ family proteins can affect junction dynamics via protein-protein interactions with junction protein complexes.

\subsubsection{TGF- $\beta$ s regulate junction restructuring}

TGF- $\beta$ s regulate junction dynamics in various cell types. For instance, TGF- $\beta 1$ can perturb the permeability of the blood-retinal barrier via a stimulation of MMP-9 production [138]. TGF- $\beta 1$ also perturbs the TJ-permeability barrier in pulmonary endothelial monolayers by inducing AJ proteins to move away from the cell-cell contact site, possibly via a myosin light chain kinase mediated mechanism [139]. TGF$\beta 1$ and Ras can also work synergistically to promote cell 
invasiveness in intestinal epithelial cells by down-regulating E-cadherin expression and subcellular redistribution of $\beta$ catenin [140]. In addition, TGF- $\beta 1$ can induce AJ disruption in renal proximal tubular epithelial cells, which cannot be reproduced by transient overexpression of $\mathrm{Smad} 2 / 4$ or Smad3/4 [141], illustrating this is an Smad-independent signaling event. On the other hand, a blockage of TGF- $\beta$ signaling by treatment of a TGF- $\beta$ receptor kinase inhibitor up-regulates $\mathrm{TJ}$ protein production (e.g., claudin-5) in embryonic stem cell-derived endothelial cells [142]. Interestingly, in almost all of these epithelial/endothelial cells, a disruption of either $\mathrm{TJ}$ or $\mathrm{AJ}$ can affect the integrity of the other junction type following an induction by TGF- $\beta$ s. Yet the functional inter-relationship of $\mathrm{AJ}$ and $\mathrm{TJ}$ in the seminiferous epithelium is significantly different from all other epithelia and endothelia. For instance, TGF- $\beta 3$ (and also TGF- $\beta 2$ in vitro) can disrupt the Sertoli-Sertoli TJbarrier by down-regulating TJ proteins (e.g., occludin) via p38 MAPK signaling pathway and this effect is indeed confirmed using an in vivo model to study the BTB dynamics $[44,113,132]$ (see Fig. 2). Analogous to other epithelia and endothelia, a breakdown of TJ can indeed affect the integrity of AJ, resulting in a loss of Sertoli-germ cell adhesion [52]. However, a disruption of AJ between Sertoli-germ and Sertoli-Sertoli cells seems to reinforce the $\mathrm{TJ}$ at the BTB instead, let alone its disruption, in the Adjudin- and intratesticular testosterone suppressioninduced germ cell loss models [2,30]. Recent studies have shown that TGF- $\beta 3$ can exert its effects on AJ integrity via a signaling pathway different from the one that regulates $\mathrm{TJ}$ dynamics in the testis [68], so that Sertoli-germ cell AJ can undergo restructuring without perturbing the BTB integrity (Fig. 2). This unique relation of $\mathrm{AJ}$ and $\mathrm{TJ}$ in the seminiferous epithelium may be a physiological requirement for the testis to facilitate germ cell migration (i.e., AJ restructuring) while maintaining $\mathrm{TJ}$ integrity. This concept will be revisited and discussed in detail in Section 5.

\subsection{Signaling regulation and selectivity}

\subsubsection{Multilayers of signal modulation}

Regulation of TGF- $\beta$-mediated signalings occurs at multiple levels: ligand production and activation, ligandreceptor coupling, intracellular signal pathway selection, nucleocytoplasmic shuttling of transcription factors, an interaction of multiple transcription factors that finally determines the activation or repression of gene expression, and signal termination [110,143-146]. Less is known regarding how the expression of TGF- $\beta$ s is regulated. The promoter sequences of human TGF- $\beta$ s have been characterized. For instance, TGF- $\beta 1$ is mostly regulated by AP- 1 site lacking TATA box, whereas TGF- $\beta 2$ and TGF- $\beta 3$ are regulated by AP-2 site and cAMP-responsive elements, containing TATA box [121], and the most potent activator of TGF- $\beta 1$ expression known thus far is the cytokine itself [147]. It has been shown that JNK suppresses the autocrine expression of TGF- $\beta 1$ in fibroblasts [148]. A recent in vivo study in the testis has shown that JNK signaling is required for the production of $\alpha_{2}-\mathrm{MG}$ in the seminiferous epithelium, which tethers TGF- $\beta 3$ and antagonizes the cytokine [114]. These results thus illustrate the TGF- $\beta$ action is regulated at multiple levels and can induce diversified biological responses. Upon secretion, TGF- $\beta$ s are tightly but noncovalently bound to LAPs, which are further tethered to latent transforming growth factor- $\beta$ binding proteins (LTBPs) via covalent bonds [149]. LTBP can covalently bind to ECM, enabling cytokines to be retained in the matrix and creates a reservoir [149]. This biologically inactive cytokine pool can be activated by low $\mathrm{pH}$, protease (e.g., plasmin, MMP-2 and MMP-9), thrombospondin-1 (TSP-1), integrin- $\alpha v \beta 6$ or $-\alpha v \beta 8[145,146,149,150]$. At least one LTBP called LTBP-1L (long form) is highly expressed in testes [150]. MMP-2 and MMP-9 are also found in the testis [97]. Other antagonists of TGF- $\beta$ s include $\alpha_{2}$-MG and decorin, which can 'lock' the ligand and prevent its binding with receptors, and endoglin, which binds to T $\beta$ RIIassociated TGF- $\beta 1$ or $-\beta 3$ and attenuates T $\beta R I$ mediated signaling $[110,151,152]$. After TGF- $\beta$ binds to its receptors, signaling is triggered but can be directed to a distinctive pathway, and can sometimes activate multiple pathways. Because of such diversified signaling capacity, a mechanism must be in place to choose the needed downstream signaling pathway. It is likely that adaptor proteins play the decisionmaking role. For instance, activation of $\operatorname{Smad} 2 / 3$ is facilitated by the adaptor SARA. Yet the detail of this selection still remains elusive. To transmit the signaling to the corresponding genes for their transcriptional induction, activated transcription factors (e.g., Smad2 and Smad3) must enter the nucleus. As such, there is constant nucleocytoplasmic shuttling of the R-Smads between active (phosphorylated) and inactive (dephosphorylated) status to keep sensing the signals at real-time $[110,144]$. The cellspecific and non-specific transcription factors/coactivator/ co-repressors can determine the final gene expression outcome in a particular cell type at the end of TGF- $\beta$ activation $[110,116]$. Receptor internalization and degradation, Smad shuttling and ubiquitination, and expression feedback can all contribute to the signal termination [118].

\subsubsection{Adaptors as molecular switches for $T G F-\beta$ signaling in the testis}

It is of interest to note that in the testis, the TGF- $\beta 3$ activated signaling can have distinctive effects on the junction restructuring. When p38 MAPK is activated by TGF- $\beta 3$, the BTB in the seminiferous epithelium is disrupted concomitant with Sertoli-germ cell AJ disassembly [52] (Fig. 2). In contrast, when ERK1/2 is activated by TGF- $\beta 3$, only AJs are affected without affecting the BTB integrity [68] (Fig. 2). Indeed, a blockade of the TGF- $\beta 3$ mediated signaling by using an antagonist (e.g., T $\beta R I I / F c$ conjugate) can prevent the activation of ERK1/2 and significantly delay the Adjudin-induced germ cell loss from 

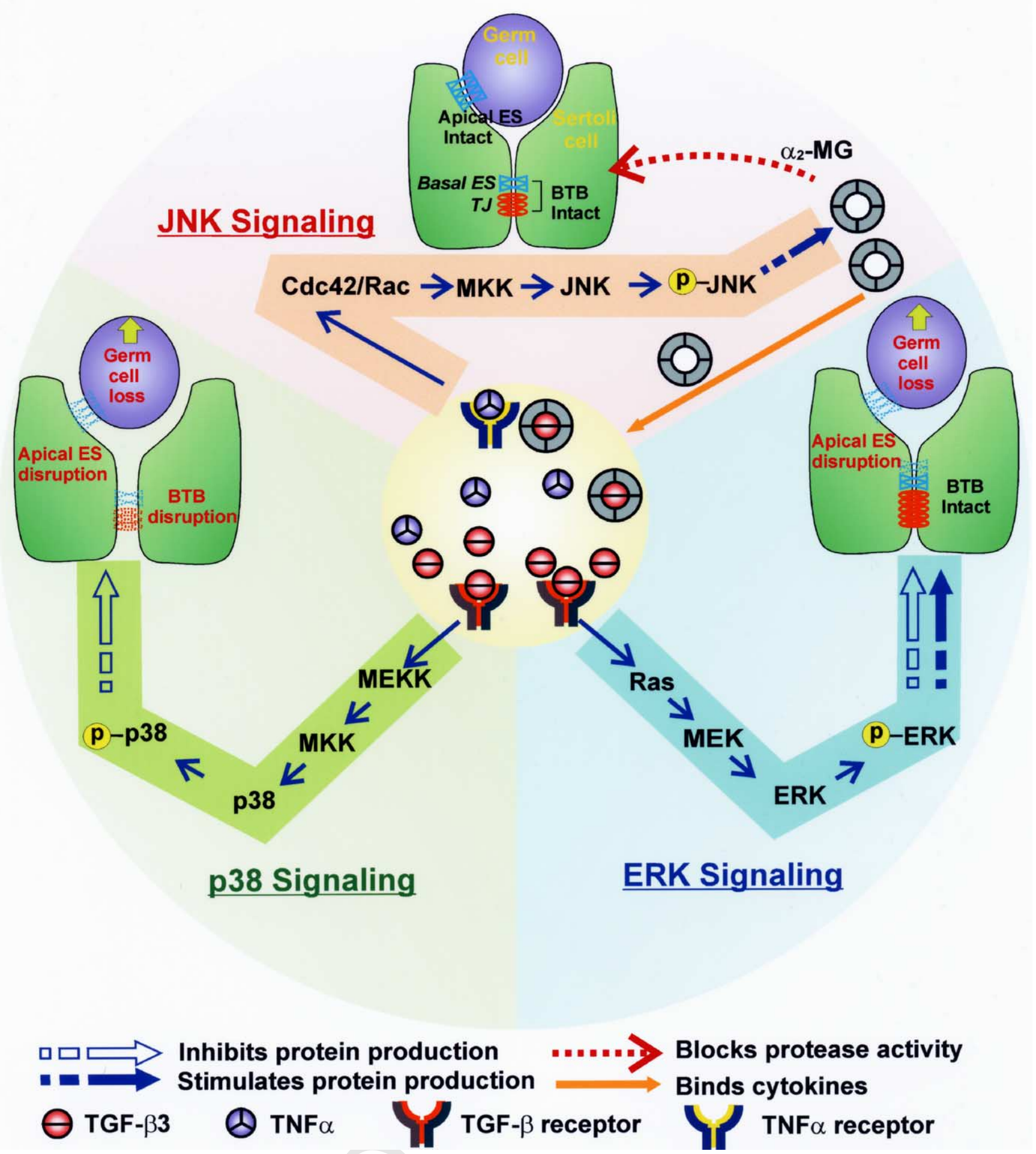

Fig. 2. A schematic illustration of how cytokines (e.g., TGF- $\beta 3, \mathrm{TNF} \alpha$ ) can regulate junction dynamics in the testis via their effects on the steady-state levels of proteins (e.g., TJ- and AJ-proteins, protease inhibitors such as $\alpha_{2}-\mathrm{MG}$ ) at the BTB and apical ES. This model was prepared based on recent studies from this laboratory using different animal models as reviewed herein. In brief, cytokines released from either Sertoli or germ cells can activate at least three different signaling pathways upon their binding to receptors. For instance, TGF- $\beta 3$ can activate p 38 MAPK signaling pathway to down-regulate both TJ and AJ proteins, resulting in the disruption of the BTB and Sertoli-germ cell adhesion function, eventually leading to germ cell loss from the epithelium (green sector), which was identified in studies using the cadmium model $[52,113,132]$. This also illustrates that when TGF- $\beta 3$ utilizes the p38 MAPK pathway for its signaling function, it can perturb both the BTB and apical ES integrity. When rats were treated with Adjudin, or testosterone/estradiol implants to reduce intratesticular androgen level, the testis responds to these treatments with an induction of TGF- $\beta 3$ that can activate only the ERK signaling pathway to compromise Sertoligerm cell adhesion function by lowering the steady-state protein levels at the apical ES or weakening protein-protein interactions at this site via changes in the phosphorylation status of adaptors (e.g., $\beta$-catenin); this in turn leads to the loss of germ cells from the epithelium, and this event does not affect the BTB 
the epithelium [68]. By blocking these two MAPK signaling pathways using kinase inhibitors can also rescue the epithelium from the disruptive effects of $\mathrm{CdCl}_{2}$ and Adjudin on the BTB and Sertoli-germ cell AJ, respectively $[52,68,113]$. As such, TGF- $\beta 3$ serves as a key regulator that decides whether BTB is affected or not. It is tempting to speculate that this TGF- $\beta$-activated MAPK signaling cascade requires the recruitment of adaptors to the site which can in turn shuttle to the correct signaling pathway downstream. Recent studies have shown that TGF- $\beta$ induced p38 MAPK activation is mediated through a protein scaffold complex XIAP (X-linked inhibitor of apoptosis)/ TAB1 (TAK binding protein)/TAK1 (TGF- $\beta$-activated kinase), in which adaptor XIAP may link adaptor TAB1 and MAPKKK TAK1 to the T $\beta R I$. T $\beta R 1$ can activate TAK1, which further activates either MKK3/6 or MKK4 that in turn activates p38 MAPK or JNK, respectively [118]. Besides, MAPKK-independent autophosphorylation of p38 is also possible, which is TAB1 dependent [153]. On the other hand, TGF- $\beta$ can activate Ras, which further activates ERK signaling pathway and regulates various cellular processes including junction dynamics [68]. TGF- $\beta$-induced ERK activation also requires the adaptor CD2-associated protein (CD2AP). When this adaptor is not involved, p38 MAPK is preferentially activated instead. In its presence, TGF- $\beta$ activates both the PI 3-kinase/Akt and the Ras/ERK pathways [154]. Interestingly, CD2AP is not involved in PI 3-kinase/Akt activation by EGF and insulin, nor in the activation of Smad 2 by TGF- $\beta$, suggesting it plays a role in TGF- $\beta$-activated, Smad-independent signaling [155]. The association between TGF- $\beta$ receptors and CD2AP is further supported by the evidence that both are present in lipid rafts $[156,157]$. Thus CD2AP can serve as a molecular switch to determine the downstream signaling direction of TGF- $\beta$. $\mathrm{CD} 2 \mathrm{AP}$ belongs to a family of ubiquitously expressed adaptors containing three Src-homology 3 (SH3) domains, a proline-rich region and a coiled-coil domain [158] and is expressed in human testes [159]. The SH3 domain mediates interaction with the p85 subunit of PI 3-kinase and the proline-rich region mediates association with p130 Cas and Src family kinases (for a review, see [158]). p130 Cas and Src are components of a signaling machinery connecting FAK, paxillin, ERK and myosin light chain kinase (MLCK), which, in turn regulate cell adhesion during cell migration process [160]. Interestingly, virtually all of these proteins have recently been found in the testis and they are likely involved in junction dynamics during spermatogenesis (for reviews, see $[2,22,97])$. It is likely that $\mathrm{CD} 2 \mathrm{AP}$ is a crucial adaptor of TGF- $\beta$ mediated and integrin/FAK mediated signaling events in the testis. Although much of the information on CD2AP derives from studies in the kidney, the testis may employ this molecular switch to select the downstream signaling pathways to be activated by TGF- $\beta 3$, affecting either AJ alone or TJ and basal ES at the BTB. This should be vigorously validated in future studies.

\section{What lessons we learn from the testis as a model to study junction restructuring?}

As we have discussed above, the testis is an intriguing organ where extensive junction restructuring occurs in the seminiferous epithelium at each stage of the epithelial cycle. Recent studies aiming to delineate the mechanisms that regulate the junction restructuring events in the testis have yielded some crucial information, which is likely applicable to general cellular physiology as a whole. Herein, we summarize several in vivo models that have been established and used in recent studies (see Table 3). We only highlight some of the latest development using these models and readers are encouraged to refer to several recent reviews $[1,2,9,75,161,162]$.

\subsection{Adjudin model}

Formerly called AF-2364 [1-(2,4-dichlorobenzyl)-1Hindazole-3-carbohydrazide], Adjudin is a molecule that selectively induces adherens junction disruption. It is a well studied potential male contraceptive derived from indazole-3carboxylic acid $[163,164]$. It is also one of the best studied compounds that induce germ cell sloughing in the testis. Adjudin apparently exerts its effects on the Sertoli-germ cell adhesion unit to induce a loss of $\mathrm{AJ}$ function by triggering a couple of signaling events, including a surge of the ESassociated signaling molecule testin, an induction of integrinand cadherin-initiated pathways, as well as TGF- $\beta 3$ activation [37,66-68,74,163,165-167]. Moreover, the ES-based $\mathrm{AJ}$ are compromised due to a loss of protein-protein association in the $\mathrm{N}$-cadherin/ $\beta$-catenin and nectin/afadin protein complexes, which is likely the result of a coordinated regulation by protein and lipid kinases and phosphatases, proteases and protease inhibitors [35,67,68,74,94]. These signalings are triggered within a few hours after adult male rats are treated with a single or multiple doses of Adjudin at

integrity (blue sector) [2,68]. This thus suggests that TGF- $\beta 3$ can limit its action at the apical ES without compromising the BTB when the ERK signaling pathway is being utilized. Using the cadmium model, it is presently known that JNK is activated during the cadmium-induced BTB damage. This induces the production of $\alpha_{2}-\mathrm{MG}$, which either bind to the free cytokines, limiting their biological action and/or blocking protease activity to limit the BTB damage. Since it is known that by blocking the production of $\alpha_{2}-\mathrm{MG}$, it can worsen the damaging effect of cadmium on testicular junctions (red sector), illustrating this JNK- $\alpha_{2}-$ MG pathway is crucial to maintain the normal physiology in the seminiferous epithelium [57,114]. This pathway is likely utilized by TNF $\alpha$ to regulate the steady-state protein level of $\alpha_{2}$-MG. The coordinated action of these three interacting signaling pathways that are intriguingly regulated by cytokines (e.g., TGF$\beta 3$ and $\mathrm{TNF} \alpha$ ) is crucial to maintain the integrity of the seminiferous epithelium during spermatogenesis, permitting selective disruption of either TJ, AJ, or TJ and AJ. As reviewed herein, it is likely that adaptors play a crucial role upstream to select which signaling pathway should be activated by these cytokines, which in turn determines if either BTB, apical ES, or both BTB and apical ES should be compromised during spermatogenesis. 
Table 3

Chemicals that target the testis and can potentially serve as models to study junction dynamics

\begin{tabular}{|c|c|c|c|c|}
\hline $\begin{array}{l}\text { Affectedjunction } \\
\text { types }\end{array}$ & Chemical & Classification & $\begin{array}{l}\text { Target junction types in the testis and } \\
\text { manifestations }\end{array}$ & References \\
\hline TJ/AJ & Cadmium & Heavy metal & $\begin{array}{l}\text { BTB/ES disruption; germ cell loss/apoptosis, } \\
\text { irreversible }\end{array}$ & {$[52,114,178,179,200]$} \\
\hline TJ & Cisplatin & Chemotherapeutic drug & BTB disruption; azoospermia, irreversible & {$[177,258,259]$} \\
\hline TJ & Glycerol & 1,2,3-Propanetriol & BTB disruption; germ cell loss, irreversible & {$[260,261]$} \\
\hline TJ & Occludin peptide & $\begin{array}{l}\text { 22-a.a. from } 2 \text { nd extracellular } \\
\text { loop of occludin }\end{array}$ & BTB disruption; germ cell loss, reversible & [262] \\
\hline $\mathrm{AJ} / \mathrm{TJ}$ & Gossypol & Extract from cotton seed oil & $\begin{array}{l}\mathrm{ES} / \mathrm{AJ} / \text { prevent BTB formation in neonatal animal; } \\
\text { germ cell loss; irreversible in neonatal animal }\end{array}$ & {$[177,263-265]$} \\
\hline $\mathrm{AJ}$ & Adjudin (AF-2364) & $\begin{array}{l}\text { Indazole-3-carboxylic } \\
\text { acid analog }\end{array}$ & ES/AJ disruption; germ cell loss, reversible & {$[163,164]$} \\
\hline $\mathrm{AJ}$ & AF-2785 & & ES/AJ disruption; germ cell loss, reversible & {$[163,164]$} \\
\hline $\mathrm{AJ}$ & Lonidamine (AF-1890) & & $\begin{array}{l}\text { ES/AJ disruption; germ cell loss; irreversible } \\
\text { in selected subjects }\end{array}$ & [266] \\
\hline $\mathrm{AJ}$ & $\begin{array}{l}\text { Testosterone/estrogen } \\
\text { implants }\end{array}$ & Steroid hormone & ES/AJ disruption; germ cell loss, reversible & {$[30,33,35,36,267,268]$} \\
\hline $\mathrm{AJ}$ & Vinclozolin & Fungicide/antiandrogen & ES/AJ (?); germ cell apoptosis & {$[180,191,269,270]$} \\
\hline $\mathrm{AJ}$ & Phthalate & $\begin{array}{l}\text { Widely used as a plasticizer } \\
\text { and in cosmetics/antiandrogen }\end{array}$ & $\begin{array}{l}\text { Basal and apical ES disruption; seminiferous } \\
\text { tubule atrophy, germ cell loss }\end{array}$ & {$[180,181,183,186]$} \\
\hline $\mathrm{AJ}$ & Bisphenol A & Plastics/estrogenic & $\begin{array}{l}\text { Apical ES disruption; abnormal spermatids, } \\
\text { acrosomal defects }\end{array}$ & {$[177,182,198,271-273]$} \\
\hline
\end{tabular}

$40-50 \mathrm{mg} / \mathrm{kg}$ b.w. either via i.p. or by gavage. Thereafter, morphological changes (i.e., germ cell depletion) are typically seen by $6-8 \mathrm{~h}$ [168]. The effect of Adjudin is limited to AJs, since the BTB remains intact in Adjudin treated rats. Furthermore, spermatogonia cell population apparently is unaffected [2]. Its antifertility effects are reversible, since the voided tubules treated with Adjudin can become repopulated with germ cells, making them almost indistinguishable from normal testes [164]. Studies from Adjudin treated rat testes have revealed some regulatory mechanisms that affect Sertoli-germ cell adhesion function pertinent to spermatogenesis. For instance, the integrin/FAK signaling is activated during Adjudin-induced germ cell loss from the epithelium [37]. This information has recently been validated and expanded using an androgen suppression-induced germ cell loss model in which rats received androgen and estrogen implants to suppress the intratesticular androgen level thereby perturbing Sertoli-germ cell apical ES function [36,37]. More important, TGF- $\beta 3$ is also induced in androgen-suppressed rat testes, similar to the Adjudin model ([68] and unpublished observations), illustrating the involvement of cytokines in cell adhesion function. It is possible that the migration of germ cells across the seminiferous epithelium during spermatogenesis is controlled by several independent signaling pathways. When an agent activates these signalings, though the initial responses are different for different agents, the net outcome (i.e., alteration in Sertoli-germ cell adhesion function and the subsequent germ cell sloughing) is similar. Indeed, the signaling events in the rat testis identified using the Adjudin model have shown that this organ is utilizing the junction restructuring events usually restricted cell-ECM interface to regulate cell adhesion, migration, tissue remodeling and development, and tumor cell metastasis [115,169,170], illustrating the cell-cell anchoring junction in the testis is indeed a hybrid cell-cell and cell-matrix junction type [22].

\subsection{Cadmium model}

Cd is a heavy metal and an environmental pollutant that is widely used in industry. It poses significant threat to human health and is classified as an endocrine disruptor [171-173]. It adversely affects a number of organs including the testis, kidney, lung, liver, pancreas and placenta $[171,173]$. The molecular mechanisms of action of cadmium toxicity are rather diverse which include: (i) binding to estrogen receptors, mimicking estrogen in the uterus and mammary gland [174]; (ii) disrupting the cadherin-based cell-cell adhesion [172]; (iii) inhibiting the DNA mismatch repair [175]; and (iv) disrupting endothelial and blood-testis barriers [52]. The testis is very sensitive to Cd exposure and the $\mathrm{Cd}$-induced testicular effects (e.g., necrosis) is common across all animal species [176]. The antifertility effect of $\mathrm{Cd}$ has been known for decades. A recent study has identified a metal transporter of Cd (ZIP8, ZRT-, IRT-like protein 8) that is highly expressed in Sertoli cells [176], which likely explains, at least in part, why this cell type is sensitive to $\mathrm{Cd}$ induced damages in the testis. Indeed, the junctional proteins are the early targets of a panel of toxicants, including $\mathrm{Cd}$, in Sertoli cells cultured in vitro [177]. At a relative low dosage of Cd (e.g., 0.1-1 $\mu \mathrm{M})$, it can reversibly perturb the Sertoli cell TJ-barrier in vitro when testosterone and FSH are present in the media [178]. Intraperitoneal administration of cadmium $(1-3 \mathrm{mg} / \mathrm{kg}$ b.w.) to adult rats can irreversibly damage the BTB, which has been used as a model to study 
1024 BTB dynamics in the testis $[52,113,114,179]$. Apparently, 1025 when absorbed by Sertoli cells, Cd targets the microfila1026 ment, causing a disorganization of actin bundles [179]. 1027 Furthermore, Cd induces the dissolution of TJ proteins (e.g., 1028 occludin) from the seminiferous epithelium, and down1029 regulates AJ-proteins (e.g., cadherin, nectin) to induce a 1030 secondary disruption of basal ES, leading to germ cell 1031 sloughing [52]. Using this model, it has been shown that the 1032 TGF- $\beta 3$ /MEKK/p38 MAPK mediated signaling pathway is 1033 a putative mechanism that regulates TJ dynamics at the BTB 1034 in vivo, and a disruption of this pathway using specific 1035 inhibitors can indeed significantly delay the $\mathrm{Cd}$ damage to 1036 the BTB as well as the subsequent germ cell loss from the 1037 epithelium $[44,113,132]$.

\subsection{Possible in vivo models to study junction dynamics in the testis}

Recent studies have illustrated a number of chemicals that can affect testicular junctions, which may be developed into useful in vivo models. Many of these molecules are endocrine disruptors, which include phthalate, bisphenol A, vinclozolin and others [180-183]. Because of their widespread distribution in the environment and potential health hazards (e.g., reproductive organs), these compounds have attracted great attention of research, particularly on their effects to the reproductive organs (e.g., testes). They affect the endocrine system either by acting as antiandrogens (e.g., phthalate, vinclozolin) or estrogens (e.g., bisphenol A) [180-183].

Phthalate and vinclozolin are compounds that can antagonize androgens. However, they exert these effects via different mechanisms: phthalate affects androgen synthesis [183] whereas the metabolites of vinclozolin are antagonists of androgen receptors [184,185]. Phthalate is found in cosmetic products (e.g., nail polishes, perfumes, hair sprays) and is widely used as a plasticizer, which can be non-covalently bound to the matrix and thereby slowly releases to the environment, and can be inhaled or adsorbed dermally [181,183]. Its toxic effects in male neonatal animals include hypospadias, reduced anogenital distance, vaginal pouch, some of which (e.g., hypospadias) are detected in humans $[180,181,183,186]$. When adults rats were treated with a single dose of di- $n$-pentyl phthalate (DPP) $(2.2 \mathrm{~g} / \mathrm{kg}$ b.w.), Sertoli cell junctions displayed abnormalities with disrupted basal ES, and apical ES was either absent or badly disorganized [187]. Interestingly, the disrupted basal ES between apposing Sertoli cells were reformed by $48 \mathrm{~h}$ after DPP treatment [187], illustrating this is a potentially useful model to study basal ES dynamics if adequately characterized. Furthermore, in DPP-treated prepubertal rats, extensive vacuolation occurs in Sertoli cells, to be followed by sloughing of germinal cells [188]. Apparently the observed effects of phthalate on germ cell loss are mediated via disruption of Sertoli-Sertoli and Sertoli-germ cell adhesion function.
Vinclozolin [3-(3,5-dichlorophenyl)-5-methyl-5-vinyloxazolidine-2,4-dione] is a fungicide that is widely used in farming industry. When adsorbed by humans or rodents, vinclozolin is metabolized to M1 (2-[[(3,5-dichlorophenyl)carbamoyl]oxy]-2-methyl-3-butenoic acid) and M2 (3',5'dichloro-2-hydroxy-2-methylbut-3-enanilide), which can bind to androgen receptors, antagonizing androgen function in vivo [184,185]. Besides its disruptive effects on reproductive organs (e.g., hypospadias, reduced anogenital distance) in male rats when exposed to vinclozolin in utero, it is neurotoxic and is an endocrine disruptor [189]. In the testis, vinclozolin can induce Leydig cell hypertrophy, reduce testis weight as a result of germ cell loss, and subsequently impair sperm production [190-192]. The direct structural damage of junctions at the Sertoli-Sertoli and Sertoli-germ cell interface following vinclozolin treatment remains to be examined.

Bisphenol A is a xenoestrogen although its bioactivity is 1000-1500-fold lower than $17 \beta$-estradiol. An ultrastructural examination of adult rat and mouse testes after treatment with bisphenol A has revealed that the apical ES was absent or badly damaged versus control animals; but, interestingly, the basal ES and BTB were not affected [182]. This information has also strengthened the notion that AJ disruption in the seminiferous epithelium can be restricted to the ES site without perturbing the TJ-barrier function at the BTB $[2,30]$ in contrast to other epithelia where a disruption of AJ can lead to a secondary damage of the TJbarrier function and vice versa [193-197]. The disruptive effects of bisphenol A and estrogens (17B-estradiol and $\beta$ estradiol-3-benzoate) on apical ES (but not basal ES and BTB, which remained intact) was also detected in maturating rats and mice that had been exposed to bisphenol A at neonatal [198]. However, these effects were not found when rats were fully mature [198]. In short, one of the target structures of this endocrine disruptor is the apical ES.

\subsection{Why is the testis a vulnerable target of environmental toxicants? A lesson to learn from the testis}

Studies on different environmental toxicants have unequivocally demonstrated that the testis is extremely vulnerable to these toxicants (for a review, see [199]). When exposed to these chemicals, Sertoli-Sertoli and Sertoli-germ cell junctions are the early targets and their subsequent dissolution is likely the result of down-regulation of junction proteins or changes in protein-protein association of the junction protein complexes [177]. Indeed, recent studies have shown that when adult rats were exposed to cadmium chloride, the BTB damage had occurred at least $24 \mathrm{~h}$ before the TJ-barrier of the microvessel in the interstitium $[114,200]$, indicating the BTB is more sensitive than the endothelial TJ-barrier in microvessels to cadmium toxicity. Subsequent analyses by immunohistochemistry and fluorescent microscopy using these rats have conclusively demonstrated a significant loss of $\mathrm{TJ}$ - and AJ-integral 
1132 proteins from the BTB site, consistent with results of 1133 immunoblot analyses [52,114]. Furthermore, a loss of 1134 protein-protein interactions of the AJ integral membrane 1135 proteins and their adaptors namely cadherin-catenin and 1136 nectin-afadin was also detected when rats were exposed to 1137 Adjudin [68], a chemical known to induce germ cell loss 1138 from the seminiferous epithelium without disrupting the TJ1139 barrier at the BTB (for reviews, see [1,2,9]). Taking 1140 collectively, these data have clearly illustrated the vulner1141 ability of the testis to environmental toxicants (e.g., 1142 cadmium) and that the proteins at the TJ and AJ sites are 1143 some of the primary targets of these toxicants. While the 1144 precise mechanism underlying such vulnerability is not fully 1145 understood, recent studies have shed new lights on this issue, 1146 which also highlights a unique opportunity to use these 1147 toxicant-induced BTB or AJ damage to the testis as novel 1148 models to study BTB dynamics, AJ restructuring pertinent to 1149 1150 1151 1152 1153 1154 1155 1156 spermatogenesis, and their regulation. Furthermore, these studies can plausibly provide new insights in developing preventive measures to antagonize these toxicants.

First, Sertoli cells are secretory cells that actively provide virtually all the necessary nutrients for germ cell development behind the BTB including metal transporters, such as transferrin, ceruoplasmin, and metallothioneins (MTs). MTs are small $\mathrm{Mr}$ proteins having high affinities for heavy metal ions including cadmium, zinc, copper and mercury. MTs are produced in virtually all mammalian tissues in response to metal ions exposure, which can detoxify heavy metals, such as cadmium (for reviews, see [201,202-205]). MTs are also important to maintain the homeostasis of essential trace elements, such as zinc and copper and are scavengers of free radicals [202,204] and protect cells from the cytotoxic effects of cadmium [206]. In the rat testis, MTs, such as MT1 and MT2, have been identified and isolated [207,208]. Recent studies have found a novel testis-specific MT-like protein called tesmin which is specifically expressed by spermatogenic cells [209]. MT1 and MT2 are products of Sertoli and germ cells, which are significantly induced after cadmium exposure [210]. Yet the production of MTs by Sertoli and germ cells are significantly lower when compared to hepatocytes in vitro in response to cadmium exposure [210]. Indeed, the quiescence of MT expression in the ventral prostate and the testis is the possible cause of their susceptibility to cadmium cytotoxicity and carcinogenicity [204,211-213].

Second, recent studies on the effects of cadmium on different cell lines, including MDCK, LLC-PK1, and Caco-2 cells, have shown that its primary target is E-cadherin (for a review, see [214]). For instance, cells that were exposed to cadmium were found to have their E-cadherin moving away from the cell-cell interface and became diffusely localized in the cytoplasm. It was postulated that cadmium may be competing to the binding of calcium to the E-cadherin, thereby perturbing the AJ function [214-217]. If this is the case, cadmium (and possibly other environmental toxicants) must first gain access to AJ to disrupt E-cadherin. In all other epithelia found in mammals, $\mathrm{AJ}$ is physically located behind the TJ since the TJ-barrier is located to the apical portion of the cell epithelium, and behind TJ lies desmosomes, which collectively known as the junctional complex. Behind the junctional complex are the gap junctions to be followed by the cell-matrix adhesion complex. As such, the TJ would seal most of the environmental toxicants off the epithelium in virtually all organs. Yet in the testis, TJ coexists with AJ and desmosome-like junctions at the BTB, which collectively lies adjacent to the basement membrane (a modified form of ECM, for a review, see [12]), closest to the interstitium. Thus, toxicants (e.g., cadmium) diffuses from the microvessels will have immediate access to the Ecadherin in the AJ (which is the cellular target of cadmium) at the BTB because there is no TJ-barrier that seals off cadmium. This, in turn, disrupts AJ, inducing germ cell loss from the epithelium as manifested by germ cell sloughing in many of these animal models using environmental toxicants. It is of interest to note that recent studies have begun to shed light on the physiological significance of such coexisting TJ and AJ at the BTB in relation to spermatogenesis. For instance, it is well understood that spermatogenesis is associated with extensive restructuring of Sertoli-Sertoli and Sertoli-germ cell interface because of the constant reshaping of germ cell shapes as a result of differentiation and germ cell movement from the basal to the adluminal compartment. If such $\mathrm{AJ}$ restructuring leads to TJ-barrier disruption as it is the case in other epithelia [193,195,197], the BTB integrity cannot be maintained, and haploid germ cell antigens cannot be sequestered from the host immune system; and such a disruption, even transiently, of the immunological barrier is detrimental to spermatogenesis. Thus, the fact that the BTB is constituted by co-existing AJ and TJ is to ensure such transient disruption of TJ during AJ restructuring in the seminiferous epithelium does not occur. Recent studies have shown that a signal that induces AJ disruption [e.g., via treatment of rats with Adjudin to induce extensive AJ restructuring that leads to germ cell loss from the epithelium, or a decline in endogenous intratesticular $\mathrm{T}$ level using androgen/estradiol transdermal implants] can lead to a surge in the production of both $\mathrm{AJ}$ (e.g., cadherins, catenins) and TJ (e.g., occludin, ZO-1) proteins [30,35,68] (Fig. 2). The increased TJ proteins are being used to reinforce the TJ-barrier integrity at the $\mathrm{BTB}$ at the time of extensive AJ restructuring. While the levels of AJ proteins are also induced, germ cells can still be dissociated from Sertoli cells because the AJ-integral membrane protein-AJ adaptor (e.g., the $\mathrm{N}$-cadherin- $\beta$-catenin protein complex) association is found to be weakened via an increase in tyrosine phosphorylation of $\beta$-catenin $[30,35,68]$. These findings are significant because it depicts the presence of a novel mechanism utilized by the testis to ensure TJ-barrier integrity while permitting $\mathrm{AJ}$ restructuring within a microenvironment such as the seminiferous epithelium. Fig. 2 is a schematic drawing that illustrates this novel mechanism of increasing AJ and TJ proteins, which is likely 
regulated by cytokines [e.g., TGF- $\beta 3$, TNF- $\alpha$ released from either Sertoli or germ cells $[57,113,123,218]]$ via the ERK signaling pathway that maintains the BTB integrity while permitting AJ restructuring, facilitating germ cell movement across the seminiferous epithelium. However, this same mechanism that is physiologically necessary to facilitate germ cell movement while maintaining BTB integrity during spermatogenesis also makes the BTB extremely vulnerable to environmental toxicants because of the unusual exposure of $\mathrm{AJ}$ structural proteins (e.g., E-cadherin) to the toxicants (e.g., cadmium).

\section{Conclusion and future perspectives}

In all animal species, cell migration and junction remodeling are naturally occurring processes. For instance, there are three types of signals that control different aspects of Drosophila border cell migration: a global steroidhormone signal to determine the timing, a highly localized cytokine signal to induce migration, and a growth factor to guide cells to their destination (for a review, see [219]). In the testis, FSH released from the pituitary and testosterone from Leydig cells may serve as the global regulatory factors. Cytokines that function as either paracrines or autocrines can in turn regulate localized signaling and processes. Several theories of germ cell movement during spermatogenesis have been proposed, and recently, we have put forth a junction restructuring theory in which cytokines, protease/ protease inhibitors, cytoskeleton regulators and junctional complex proteins are all coordinated to facilitate germ cell movement in the epithelium [2]. Stem cell research has also offered new insights on Sertoli-germ cell interactions and may facilitate the research regarding the local regulatory function of cytokines in this event. When rat spermatogonia are transplanted into recipient mouse testes, the rat stem cells develop according to their only timing ( $\sim 7$ week instead of $\sim 5$ week), irrespective to the surrounding mouse spermatogenesis milieu [220]. It seems that this internal preprogrammed rhythm autonomously determines the fate of rat spermatogonia differentiation, and creates a suitable localized environment through dialogues with mouse Sertoli cells, probably via cytokines for crosstalk. This intrinsic preprogrammed timing may be controlled or executed by homeobox genes. A homeobox gene cluster Rhox (reproductive homeobox on the $\mathrm{X}$ chromosome) has recently been identified in mice [221]. The 12 Rhox genes are expressed mostly in reproductive organs (placenta, ovary, testis and epididymis), arranged into three subclusters and manifested temporal and quantitative colinearity in expression patterns [221]. In the testis, the majority of Rhox genes are primarily expressed in Sertoli cells and androgen responsive [221]. During the first wave of spermatogenesis, the timing of Rhox genes expression corresponds to the specific phases of germ cell differentiation. Hence these transcription factors may direct the expression of an array of proteins required for germ cell development, and may also define the corresponding timing of epithelial cycle and length of spermatogenesis in rodents [221].

Several approaches can be used in future studies to aid the understanding of Sertoli-germ cell crosstalk and junction restructuring. First, development of testis-specific knockout mice against crucial proteins pertinent to junction restructuring and spermatogenesis to identify the function of these proteins in the testis. For many cytokines (e.g., TGF- $\beta$ s), their deletion can lead to lethality of the null mice. As such, their roles in spermatogenesis at adulthood cannot be examined. In the rat, the first wave of spermiation occurs only by 30-40 days of age. Recently conditional knockout technique has allowed investigators to elucidate protein function in a tissue- and time-specific manner in testis using specific Sertoli cell KOs, such as androgen receptor [222]. The generation of testis-specific KOs (e.g., TGF- $\beta 3$ ) will help define the roles of these cytokines in junction dynamics at spermatogenesis. Second, germline stem cell transplantation with traceable markers to follow germ cell differentiation as well as junction remodeling during spermatogenesis can assist the study of cell-cell interactions pertinent to germ cell movement. For instance, when spermatogonia are transplanted into the recipient testis, they can migrate to the basal niche and initiate spermatogenesis in the preprogrammed cycle independent of the host environment. This migration must traverse the $\mathrm{BTB}$, differing from gonocyte migration in the tubule when BTB has not yet formed. Third, using microarray technique to identify the expression profiles of various cytokines, proteases and protease inhibitors, junctional proteins, adaptors and transcription factors in staged tubules and in testes obtained from selected in vivo models. This approach can also pinpoint the leading and supporting biological factors pertinent to spermatogenesis. It is hopeful that using these approaches, a better understanding of spermatogenesis can emerge, which should be helpful for various applications such as treating male infertility or for contraception.

\section{Acknowledgements}

Supported in part by grants from the National Institutes of Health (NICHD, 5U01 HD045908 to CYC; 5U54 HD029990, Project 3 to CYC), and the CONRAD Program (CICCR, C1G 01-72 to CYC, CIG 01-74 to DDM).

\section{References}

[1] Cheng CY, Mruk DD. Cell junction dynamics in the testis: Sertoligerm cell interactions and male contraceptive development. Physiol Rev 2002;82:825-74.

[2] Mruk DD, Cheng CY. Sertoli-Sertoli and Sertoli-germ cell interactions and their significance in germ cell movement in the seminiferous epithelium during spermatogenesis. Endocr Rev 2004;25: 747-806. 
[3] de Kretser DM, Kerr JB. The cytology of the testis. In: Knobil E, Neill JD, editors. The physiology of reproduction. New York: Raven Press; 1994. p. 1177-300.

[4] Parvinen M. Regulation of the seminiferous epithelium. Endocr Rev 1982;3:404-17.

[5] Griswold M. Interactions between germ cells and Sertoli cells in the testis. Biol Reprod 1995;52:211-6.

[6] Kierszenbaum AL. Mammalian spermatogenesis in vivo and in vitro: a partnership of spermatogenic and somatic cell lineages. Endocr Rev 1994;15:116-34.

[7] Griswold MD. The central role of Sertoli cells in spermatogenesis. Semin Cell Dev Biol 1998;9:411-6.

[8] Russell LD. Movement of spermatocytes from the basal to the adluminal compartment of the rat testis. Am J Anat 1977;148:313-28.

[9] Mruk DD, Cheng CY. Cell-cell interactions at the ectoplasmic specialization in the testis. Trends Endocr Metab 2004;15:439-47.

[10] Russell L. Sertoli-germ cell interactions: a review. Gamete Res 1980;3:179-202.

[11] Gnessi L, Fabbri A, Spera G. Gonadal peptides as mediators of development and functional control of the testis: an integrated system with hormones and local environment. Endocr Rev 1997;18:541-609.

[12] Dym M. Basement membrane regulation of Sertoli cells. Endocr Rev 1994;15:102-15.

[13] Weber JE, Russell LD, Wong V, Peterson RN. Three-dimensional reconstruction of a rat stage V Sertoli cell. II. Morphometry of Sertoli-Sertoli and Sertoli-germ-cell relationships. Am J Anat 1983;167:163-79.

[14] Hess RA, Franca LR. Structure of the Sertoli cell. In: Skinner MK, Griswold MD, editors. Sertoli cell biology.. San Diego: Elsevier Academic Press; 2005. p. 19-40.

[15] Alberts B, Johnson A, Lewis J, Raff M, Roberts K, Watter P. Molecular Biology of the Cell. New York Garland Science, 2002.

[16] Toyama Y, Maekawa M, Yuasa S. Ectoplasmic specializations in the Sertoli cell: news vistas based on genetic defects and testicular toxicology. Anat Sci Int 2003;78:1-16.

[17] Lee NPY, Cheng CY. Ectoplasmic specialization, a testis-specific cell-cell actin-based adherens junction type: is this a potential target for male contraceptive development? Hum Reprod Update 2004;10:349-69.

[18] Guttman JA, Takai Y, Vogl AW. Evidence that tubulobulbar complexes in the seminiferous epithelium are involved with internalization of adhesion junctions. Biol Reprod 2004;71:548-59.

[19] Cunha-Vaz JG. The blood-retinal barriers system. Basic concepts and clinical evaluation. Exp Eye Res 2004;78:715-21.

[20] Rubin LL, Staddon JM. The cell biology of the blood-brain barrier. Annu Rev Neurosci 1999;22:11-28.

[21] Dejana E. Endothelial cell-cell junctions: happy together. Nat Rev Mol Cell Biol 2004;5:261-70.

[22] Siu MKY, Cheng CY. Dynamic cross-talk between cells and the extracellular matrix in the testis. BioEssays 2004;26:978-92.

[23] Tsukita S, Furuse M, Itoh M. Multifunctional strands in tight junctions. Nat Rev Mol Cell Biol 2001;2:285-93.

[24] Schneeberger EE, Lynch RD. The tight junction: a multifunctional complex. Am J Physiol Cell Physiol 2004;286:C1213-28.

[25] Bazzoni G. The JAM family of junctional adhesion molecules. Curr Opin Cell Biol 2003;15:525-30.

[26] Ebnet K, Suzuki A, Ohno S, Vestweber D. Junctional adhesion molecules (JAMs): more molecules with dual functions? J Cell Sci 2004;117:19-29.

[27] Martin-Padura I, Lostaglio S, Schneemann M, Williams L, Romano $\mathrm{M}$, Fruscella $\mathrm{P}$, et al. Junctional adhesion molecule, a novel member of the immunoglobulin superfamily that distributes at intercellular junctions and modulates monocyte transmigration. J Cell Biol 1998;142:117-27.

[28] Hirabayashi S, Tajima M, Yao I, Nishimura W, Mori H, Hata Y. JAM4, a junctional cell adhesion molecule interacting with a tight junction protein, MAGI-1. Mol Cell Biol 2003;23:4267-82.
[29] Gliki G, Ebnet K, Aurrand-Lions M, Lmhot BA, Adams RH. Spermatid differentiation requires the assembly of a cell polarity complex downstream of junctional adhesion molecule-C. Nature 2004;431:320-4.

[30] Xia W, Wong CH, Lee NPY, Lee WM, Cheng CY. Disruption of Sertoli-germ cell adhesion function in the seminiferous epithelium of the rat testis can be limited to adherens junctions without affecting the blood-testis barrier integrity: an in vivo study using an androgen suppression model. J Cell Physiol, in press.

[31] Cera MR, Del Prete A, Vecchi A, Corada M, Martin-Padura I, Motoike T, et al. Increased DC trafficking to lymph nodes and contact hypersensitivity in junctional adhesion molecule-A-deficient mice. J Clin Invest 2004;114:729-38.

[32] Liang TW, Chiu HH, Gurney A, Sidle A, Tumas DB, Schow P, et al. Vascular endothelial-junctional adhesion molecule (VE-JAM)/JAM 2 interacts with T, NK, and dendritic cells through JAM 3. J Immunol 2002;168:1618-26.

[33] McLachlan RI, Wreford NG, Meachem SJ, Kretser DMD, Robertson DM. Effects of testosterone on spermatogenic cell populations in the adult rat. Biol Reprod 1994;51:945-55.

[34] O’Donnell L, McLachlan RI, Wreford NG, de Kretser DM, Robertson DM. Testosterone withdrawal promotes stage-specific detachment of round spermatids from the at seminiferous epithelium. Biol Reprod 1996;55:895-901.

[35] Zhang J, Wong CH, Xia W, Mruk DD, Lee NPY, Lee WM, et al. Regulation of Sertoli-germ cell adherens junction dynamics via changes in protein-protein interactions of the $\mathrm{N}$-cadherin- $\beta$-catenin protein complex which are possibly mediated by c-Src and MTMR2: an in vivo study using an androgen suppression model. Endocrinology 2005;146:1268-84.

[36] Wong CH, Xia W, Lee NPY, Mruk DD, Lee WM, Cheng CY. Regulation of ectoplasmic specialization dynamics in the seminiferous epithelium by focal adhesion-associated proteins in testosterone-suppressed rat testes. Endocrinology 2005;146: 1192-204.

[37] Siu MKY, Mruk DD, Lee WM, Cheng CY. Adhering junction dynamics in the testis are regulated by an interplay of $\beta 1$-integrin and the focal adhesion complex-associated proteins. Endocrinology 2003;144:2141-63.

[38] Shaw SK, Perkins BN, Lim YC, Liu Y, Nusrat A, Schnell FJ, et al. Reduced expression of junctional adhesion molecule and platelet/ endothelial cell adhesion molecule-1 (CD31) at human vascular endothelial junctions by cytokines tumor necrosis factor- $\alpha$ plus interferon-gamma does not reduce leukocyte transmigration under flow. Am J Pathol 2001;159:2281-91.

[39] Turksen K, Troy T-C. Barriers built on claudins. J Cell Sci 2004; 117:2435-47.

[40] Tsukita S, Furuse M. The structure and function of claudins, cell adhesion molecules at tight junctions. Ann N Y Acad Sci 2000;915:129-35.

[41] Heiskala M, Peterson PA, Yang Y. The roles of claudin superfamily proteins in paracellular transport. Traffic 2001;2:92-8.

[42] Florin A, Maire M, Bozec A, Hellani A, Chater S, Bars R, et al. Androgens and postmeiotic germ cells regulate claudin11 expression in rat Sertoli cells. Endocrinology 2005;146:153240.

[43] Hellani A, Ji J, Mauduit C, Deschildre C, Tabone E, Benahmed M. Developmental and hormonal regulation of the expression of oligodendrocyte-specific protein/claudin 11 in mouse testis. Endocrinology 2000;141:3012-9.

[44] Lui WY, Lee WM, Cheng CY. Transforming growth factor- $\beta 3$ perturbs the inter-Sertoli tight junction permeability barrier in vitro possibly mediated via its effects on occludin, zonula occludens-1, and claudin-11. Endocrinology 2001;142:1865-77.

[45] Morita K, Sasaki H, Fujimoto K, Furuse M, Tsukita S. Claudin11/OSP-based tight junctions of myelin sheaths in brain and Sertoli cells in testis. J Cell Biol 1999;145:579-88. 
1482

1483

1484

1485

1486

1487

1488

1489

1490

1491

1492

1493

1494

1495

1496

1497

1498

1499

1500

1501

1502

1503

1504

1505

1506

1507

1508

1509

1510

1511

1512

1513

1514

1515

1516

1517

1518

1519

1520

1521

1522

1523

1524

1525

1526

1527

1528

1529

1530

1531

1532

1533

1534

1535

1536

1537

1538

1539

1540

1541

1542

1543

1544

1545

1546

1547

1548
[46] Gow A, Southwood CM, Li JS, Pariali M, Riordan GP, Brodie SE, et al. CNS myelin and Sertoli cell tight junction strands are absent in Osp/claudin-11 null mice. Cell 1999;99:649-59.

[47] Gye MC. Changes in the expression of claudins and transepithelial electrical resistance of mouse Sertoli cells by Leydig cell coculture. Int J Androl 2003;26:271-8.

[48] Kitajiri S-I, Miyamoto T, Mineharu A, Sonoda N, Furuse K, Hata M, et al. Compartmentalization established by claudin-11-based tight junctions in stria vascularis is required for hearing through generation of endocochlear potential. J Cell Sci 2004;117:5087-96.

[49] Sasaki H, Matsui C, Furuse K, Mimori-Kiyosue Y, Furuse M, Tsukita S. Dynamic behavior of paired claudin strands within apposing plasma membranes. Proc Natl Acad Sci USA 2003;100:3971-6.

[50] Matsuda M, Kubo A, Furuse M, Tsukita S. A peculiar internalization of claudins, tight junction-specific adhesion molecules, during the intercellular movement of epithelial cells. J Cell Sci 2004;117:124757.

[51] Furuse M, Hirase T, Itoh M, Nagafuchi A, Yonemura S, Tsukita S. Occludin: a novel integral membrane protein localizing at tight junctions. J Cell Biol 1993;123:1777-88.

[52] Wong CH, Mruk DD, Lui WY, Cheng CY. Regulation of blood-testis barrier dynamics: an in vivo study. J Cell Sci 2004;117:783-98.

[53] Lui WY, Lee WM. cAMP perturbs inter-Sertoli tight junction permeability barrier in vitro via its effect on proteasome-sensitive ubiquitination of occludin. J Cell Physiol 2005;203:564-72.

[54] Coyne CB, Vanhook MK, Gambling TM, Carson JL, Boucher RC, Johnson LG. Regulation of airway tight junctions by proinflammatory cytokines. Mol Biol Cell 2002;13:3218-34.

[55] Mankertz J, Tavalali S, Schmitz H, Mankertz A, Riecken EO, Fromm $\mathrm{M}$, et al. Expression from the human occludin promoter is affected by tumor necrosis factor alpha and interferon gamma. J Cell Sci 2000;113:2085-90.

[56] Yamamoto T, Kojima T, Murata M, Takano K, Go M, Chiba H, et al. IL-1 beta regulates expression of $\mathrm{Cx} 32$, occludin, and claudin- 2 of rat hepatocytes via distinct signal transduction pathways. Exp Cell Res 2004;299:427-41.

[57] Siu MKY, Lee WM, Cheng CY. The interplay of collagen IV, tumor necrosis factor- $\alpha$, gelatinase B (matrix metalloprotease-9), and tissue inhibitor of metalloproteases-1 in the basal lamina regulates Sertoli cell-tight junction dynamics in the rat testis. Endocrinology 2003; 144:371-87.

[58] Mealy K, Robinson B, Millette CF, Majzoub J, Wilmore DW. The testicular effects of tumor necrosis factor. Ann Surg 1990;211:470-5.

[59] Wheelock MJ, Johnson KR. Cadherins as modulators of cellular phenotype. Annu Rev Cell Dev Biol 2003;19:207-35.

[60] Yagi T, Takeichi M. Cadherin superfamily genes: functions, genomic organization, and neurologic diversity. Genes Dev 2000;14:1169-80.

[61] Gooding JM, Yap KL, Ikura M. The cadherin-catenin complex as a focal point of cell adhesion and signalling: new insights from threedimensional structures. BioEssays 2004;26:497-511.

[62] Angst BD, Marcozzi C, Magee AI. The cadherin superfamily: diversity in form and function. J Cell Sci 2001;114:629-41.

[63] Johnson KJ, Patel SR, Boekelheide K. Multiple cadherin superfamily members with unique expression profiles are produced in rat testis. Endocrinology 2000;141:675-83.

[64] Peinado H, Portillo F, Cano A. Transcriptional regulation of cadherins during development and carcinogenesis. Int $\mathrm{J}$ Dev Biol 2004;48:365-75.

[65] Johnson KJ, Boekelheide K. Dynamic testicular adhesion junctions are immunologically unique. II. Localization of classic cadherins in rat testis. Biol Reprod 2002;66:992-1000.

[66] Lee NPY, Mruk D, Lee WM, Cheng CY. Is the cadherin/catenin complex a functional unit of cell-cell actin-based adherens junctions in the rat testis? Biol Reprod 2003;68:489-508.

[67] Lee NPY, Mruk DD, Conway AM, Cheng CY. Zyxin, axin, and Wiskott-Aldrich syndrome protein are adaptors that link the cadherin/catenin protein complex to the cytoskeleton at adherens junc- tions in the seminiferous epithelium of the rat testis. J Androl 2004;25:200-15.

[68] Xia W, Cheng CY. TGF- $\beta 3$ regulates anchoring junction dynamics in the seminiferous epithelium of the rat testis via the Ras/ ERK signaling pathway: an in vivo study. Dev Biol 2005;280: 321-43.

[69] Wine RN, Chapin RE. Adhesion and signaling proteins spatiotemporally associated with spermiation in the rat. J Androl 1999;20:198213.

[70] Johnson KJ, Zecevic A, Kwon EJ. Protocadherin $\alpha 3$ acts at sites distinct from classic cadherins in rat testis and sperm. Biol Reprod 2004;70:303-12.

[71] Wheelock MJ, Johnson KR. Cadherin-mediated cellular signaling. Curr Opin Cell Biol 2003;15:509-14.

[72] Perez-Moreno M, Jamora C, Fuchs E. Sticky business: orchestrating cellular signals at adherens junctions. Cell 2003;112:535-48.

[73] Daniel JM, Reynolds AB. Tyrosine phosphorylation and cadherin/ catenin function. BioEssays 1997;19:883-91.

[74] Lee NPY, Cheng CY. Protein kinases and adherens junction dynamics in the seminiferous epithelium of the rat testis. J Cell Physiol 2005;202:344-60.

[75] Zhang J, Mruk DD, Cheng CY. Myotubularin phosphoinositide phosphatases, proteins phosphatases, and kinases: their roles in junction dynamics and spermatogenesis. J Cell Physiol, in press.

[76] Lui WY, Mruk D, Cheng CY. Interactions among IQGAP1, Cdc42, and the cadherin/catenin protein complex regulate Sertoli-germ cell adherens junction dynamics in the testis. J Cell Physiol 2005;202:4966.

[77] Hazan RB, Qiao R, Keren R, Badano I, Suyama K. Cadherin switch in tumor progression. Ann N Y Acad Sci 2004;1014:155-63.

[78] Derycke LDM, Bracke ME. N-cadherin in the spotlight of cell-cell adhesion, differentiation, embryogenesis, invasion and signaling. Int J Dev Biol 2004;48:463-76.

[79] Takai Y, Nakanishi H. Nectin and afadin: novel organizers of intercellular junctions. J Cell Sci 2003;116:17-27.

[80] Satoh-Horikawa K, Nakanishi H, Takahashi K, Miyahara M, Nishimura M, Tachibana K, et al. Nectin-3, a new member of immunoglobulin-like cell adhesion molecules that shows homophilic and heterophilic cell-cell adhesion activities. J Biol Chem 2000;275: 10291-9.

[81] Reymond N, Fabre S, Lecocq E, Adelaide J, Dubreuil P, Lopez M. Nectin4/PRR4, a new afadin-associated member of the nectin family that trans-interacts with nectin1/PRR1 through V domain Interaction. J Biol Chem 2001;276:43205-15.

[82] Takahashi K, Nakanishi H, Miyahara M, Mandai K, Satoh K, Satoh A, et al. Nectin/PRR: an immunoglobulin-like cell Adhesion molecule recruited to cadherin-based adherens junctions through interaction with afadin, a PDZ domain-containing protein. J Cell Biol 1999; 145:539-49.

[83] Ozaki-Kuroda K, Nakanishi H, Ohta H, Tanaka H, Kurihara H, Mueller S, et al. Nectin couples cell-cell adhesion and the actin scaffold at heterotypic testicular junctions. Curr Biol 2002;12:114550.

[84] Bouchard MJ, Dong Jr Y, McDermott Jr BM, Lam D-H, Brown KR, Shelanski M, et al. Defects in nuclear and cytoskeletal morphology and mitochondrial localization in spermatozoa of mice lacking nectin-2, a component of cell-cell adherens junctions. Mol Cell Biol 2000;20:2865-73.

[85] Mueller S, Rosenquist TA, Takai Y, Bronson RA, Wimmer E. Loss of nectin-2 at Sertoli-spermatid junctions leads to male infertility and correlates with severe spermatozoan head and midpiece malformation, impaired binding to the zona pellucida, and oocyte penetration. Biol Reprod 2003;69:1330-40.

[86] Fukuhara T, Shimizu K, Kawakatsu T, Fukuyama T, Minami Y, Honda T, et al. Activation of $\mathrm{Cdc} 42$ by trans interactions of the cell adhesion molecules nectins through c-Src and Cdc42-GEF FRG. J Cell Biol 2004;166:393-405. 
[87] Takai Y, Irie K, Shimizu K, Sakisaka T, Ikeda W. Nectins and nectinlike molecules: roles in cell adhesion, migration, and polarization. Cancer Sci 2003;94:655-67.

[88] Sakisaka T, Takai Y. Biology and pathology of nectins and nectin-like molecules. Curr Opin Cell Biol 2004;16:513-21.

[89] Irie K, Shimizu K, Sakisaka T, Ikeda W, Takai Y. Roles and modes of action of nectins in cell-cell adhesion. Semin Cell Dev Biol 2004;15:643-56.

[90] Asada M, Irie K, Morimoto K, Yamada A, Ikeda W, Takeuchi M, et al. ADIP, a novel afadin- and $\alpha$-actinin-binding protein localized at cell-cell adherens junctions. J Biol Chem 2003;278:410311.

[91] Tachibana K, Nakanishi H, Mandai K, Ozaki K, Ikeda W, Yamamoto $\mathrm{Y}$, et al. Two cell adhesion molecules, nectin and cadherin, interact through their cytoplasmic domain-associated proteins. J Cell Biol 2000;150:1161-76.

[92] Ooshio T, Irie K, Morimoto K, Fukuhara A, Imai T, Takai Y. Involvement of LMO7 in the association of two cell-cell adhesion molecules, nectin and E-cadherin, through afadin and $\alpha$-actinin in epithelial cells. J Biol Chem 2004;279:31365-73.

[93] Shingai T, Ikeda W, Kakunaga S, Morimoto K, Takekuni K, Itoh S, et al. Implications of nectin-like molecule-2/IGSF4/RA175/SgIGSF/ TSLC1/SynCAM1 in cell-cell adhesion and transmembrane protein localization in epithelial cells. J Biol Chem 2003;278:35421-7.

[94] Siu MKY, Cheng CY. Interactions of proteases, protease inhibitors, and the $\beta 1$ integrin/laminin $\gamma 3$ protein complex in the regulation of ectoplasmic specialization dynamics in the rat testis. Biol Reprod 2004;70:945-64.

[95] Hynes RO. Integrins: bidirectional, allosteric signaling machines. Cell 2002;110:673-87.

[96] Jin H, Varner J. Integrins: roles in cancer development and as treatment targets. Br J Cancer 2004;90:561-5.

[97] Siu MKY, Cheng CY. Extracellular matrix: recent advances on its role in junction dynamics in the seminiferous epithelium during spermatogenesis. Biol Reprod 2004;375-91.

[98] Vilcek J. The cytokines: an overview. In: Thomson AW, Lotze MT, editors. The cytokine handbook. Academic Press; 2003. p. 3-18.

[99] Mruk DD, Cheng CY. Sertoli cell proteins in testicular paracriny. In: Jegou B, Pineau C, Saez J, editors. Testis, epididymis and technologies in the year 2000. Berlin: Springer-Verlag; 2000. p. 197-228.

[100] Bardin CW, Cheng CY, Mustow NA, Gunsalus GL. The Sertoli cell. In: Knobil E, Neill JD, editors. The physiology of reproduction. New York: Raven Press; 1994. p. 1291-332.

[101] Wang H, Czura CJ, Tracey KJ. Tumor necrosis factor. In: Thomson AW, Lotze MT, editors. The cytokine handbook. Academic Press; 2003. p. 837-60.

[102] Mocellin S, Rossi CR, Pilati P, Nitti D. Tumor necrosis factor, cancer and anticancer therapy. Cytokine Growth Factor Rev 2005;16:35-53.

[103] Aggarwal BB. Signalling pathways of the TNF superfamily: a double-edged sword. Nat Rev Immunol 2003;3:745-56.

[104] Soond SM, Terry JL, Colbert JD, Riches DWH. TRUSS, a novel tumor necrosis factor receptor 1 scaffolding protein that mediates activation of the transcription factor NF-кB. Mol Cell Biol 2003;23:8334-44.

[105] Gibson PR. Increased gut permeability in Crohn's disease: is TNF the link? Gut 2004;53:1724-5.

[106] Hong CY, Park JH, Ahn RS, Im SY, Choi H-S, Soh J, et al. Molecular mechanism of suppression of testicular steroidogenesis by proinflammatory cytokine tumor necrosis factor $\alpha$. Mol Cell Biol 2004;24:2593-604.

[107] Pentikainen V, Erkkila K, Suomalainen L, Otala M, Pentikainen MO, Parvinen M, et al. TNF $\alpha$ down-regulates the Fas ligand and inhibits germ cell apoptosis in the human testis. J Clin Endocrinol Metab 2001;86:4480-8.

[108] Morales V, Santana P, Diaz R, Tabraue C, Gallardo G, Blanco FL, et al. Intratesticular delivery of tumor necrosis factor- $\alpha$ and ceramide directly abrogates steroidogenic acute regulatory protein expression and Leydig cell steroidogenesis in adult rats. Endocrinology 2003; 144:4763-72.

[109] Chang H, Brown CW, Matzuk MM. Genetic analysis of the mammalian transforming growth factor- $\beta$ superfamily. Endocr Rev 2002;23:787-823.

[110] Shi Y, Massague J. Mechanisms of TGF- $\beta$ signaling from cell membrane to the nucleus. Cell 2003;113:685-700.

[111] Behringer RR, Finegold MJ, Cate RL. Mullerian-inhibiting substance function during mammalian sexual development. Cell 1994;79:415-25.

[112] Ingman WV, Robertson SA. Defining the action of transforming growth factor $\beta$ in reproduction. BioEssays 2002;24:904-14.

[113] Lui WY, Wong CH, Mruk DD, Cheng CY. TGF- $\beta 3$ regulates the blood-testis barrier dynamics via the p38 mitogen activated protein (MAP) kinase pathway: an in vivo study. Endocrinology 2003;144: 1139-42.

[114] Wong CH, Mruk DD, Siu MKY, Cheng CY. Blood-testis barrier dynamics are regulated by $\alpha_{2}$-macroglobulin via the c-Jun N-terminal protein kinase pathway. Endocrinology 2005;146:1893-908.

[115] Wakefield LM, Roberts AB. TGF- $\beta$ signaling: positive and negative effects on tumorigenesis. Curr Opin Genet Dev 2002;12:22-9.

[116] Massague J. How cells read TGF- $\beta$ signals. Nat Rev Mol Cell Biol 2000;1:169-78.

[117] Leask A, Abraham DJ. TGF- $\beta$ signaling and the fibrotic response. FASEB J 2004;18:816-27.

[118] Derynck R, Zhang YE. Smad-dependent and Smad-independent pathways in TGF- $\beta$ family signaling. Nature 2003;425:577-84.

[119] Lui WY, Lee WM, Cheng CY. TGF- $\beta$ s: their role in testicular function and Sertoli cell tight junction dynamics. Int $\mathbf{J}$ Androl 2003;26:1-14.

[120] Howe PH. Transforming growth factor $\beta$. In: Thomson AW, Lotze MT, editors. The cytokine handbook. Academic Press; 2003.p. $1119-52$.

[121] Roberts AB, Kim SJ, Noma T, Glick AB, Lafyatis R, Lechleider R, et al. Multiple forms of TGF- $\beta$ : distinct promoters and differential expression. Ciba Found Symp 1991;157:7-15.

[122] Miller DA, Pelton RW, Derynck R, Moses HL. Transforming growth factor- $\beta$-a family of growth regulatory peptides. Ann N Y Acad Sci 1990;593:209-17.

[123] Mullaney BP, Skinner MK. Transforming growth factor- $\beta$ ( $\beta 1, \beta 2$, and $\beta 3$ ) gene expression and action during pubertal development of the seminiferous tubule: potential role at the onset of spermatogenesis. Mol Endocrinol 1993;7:67-76.

[124] Massague J. TGF- $\beta$ signal transduction. Annu Rev Biochem 1998;67:753-91.

[125] Massague J, Chen Y-G. Controlling TGF- $\beta$ signaling. Genes Dev 2000;14:627-44.

[126] Xu J, Beyer AR, Walker WH, McGee EA. Developmental and stagespecific expression of Smad2 and Smad3 in rat testis. J Androl 2003;24:192-200.

[127] Luukko K, Ylikorkala A, Makela TP. Developmentally regulated expression of Smad3, Smad4, Smad6, and Smad7 involved in TGF- $\beta$ signaling. Mech Dev 2001;101:209-12.

[128] Yingling JM, Blanchard KL, Sawyer JS. Development of TGF- $\beta$ signalling inhibitors for cancer therapy. Nat Rev Drug Disc 2004;3:1011-22.

[129] Widmann C, Gibson S, Jarpe MB, Johnson GL. Mitogen-activated protein kinases: conservation of a three-kinase module from yeast to human. Physiol Rev 1999;79:143-80.

[130] Peason G, Robinson F, Bibson TB, Xu B-E, Karandikar M, Berman $\mathrm{K}$, et al. Mitogen-activated protein (MAP) kinase pathways: regulation and physiological functions. Endocr Rev 2001;22:153-83.

[131] Kyriakis JM, Avruch J. Mammalian mitogen-activated protein kinase signal transduction pathways activated by stress and inflammation. Physiol Rev 2001;81:807-69.

[132] Lui WY, Lee WM, Cheng CY. Transforming growth factor- $\beta 3$ regulates the dynamics of Sertoli cell tight junctions via the $\mathrm{p} 38$
1683

1684

1685

1686

1687

1688

1689

1690

1691

1692

1693

1694

1695

1696

1697

1698 
mitogen-activated protein kinase pathway. Biol Reprod 2003;68: 1597-612.

[133] Chapin RE, Wine RN, Harris MW, Borchers CH, Haseman JK. Structure and control of a cell-cell adhesion complex associated with spermiation in rat seminiferous epithelium. J Androl 2001; 22:1030-52.

[134] Barrios-Rodiles M, Brown KR, Ozdamar B, Bose R, Liu Z, Donovan RS, et al. High-throughput mapping of a dynamic signaling network in mammalian cells. Science 2005;307:1621-5.

[135] Ozdamar B, Bose R, Barrios-Rodiles M, Wang H-R, Zhang Y, Wrana JL. Regulation of the polarity protein Par6 by TGF $\beta$ receptors controls epithelial cell plasticity. Science 2005;307:1603-9.

[136] Wang H-R, Zhang Y, Ozdamar B, Ogunjimi AA, Alexandrova E, Thomsen GH, et al. Regulation of cell polarity and protrusion formation by targeting RhoA for degradation. Science 2003;302: 1775-9.

[137] Hassel S, Eichner A, Yakymovych M, Hellman U, Knaus P, Souchelnytskyi S. Proteins associated with type II bone morphogenetic protein receptor (BMPR-II) and identified by two-dimensional gel electrophoresis and mass spectrometry. Proteomics 2004;4:1346-58.

[138] Behzadian MA, Wang X-L, Windsor LJ, Ghaly N, Caldwell RB. TGF- $\beta$ increases retinal endothelial cell permeability by increasing MMP-9: possible role of glial cells in endothelial barrier function. Invest Ophthalmol Vis Sci 2001;42:853-9.

[139] Hurst IV V, Goldberg PL, Minnear FL, Heimark RL, Vincent PA. Rearrangement of adherens junctions by transforming growth factor31: role of contraction. Am J Physiol Lung Cell Mol Physiol 1999;276:L582-95.

[140] Fujimoto K, Sheng H, Shao J, Beauchamp RD. Transforming growth factor- $\beta 1$ promotes invasiveness after cellular transformation with activated Ras in intestinal epithelial cells. Exp Cell Res 2001;266: $239-49$.

[141] Tian YC, Fraser D, Attisano L, Phillips AO. TGF- $\beta 1$-mediated alterations of renal proximal tubular epithelial cell phenotype. Am J Physiol Renal Physiol 2003;285:F130-42.

[142] Watabe T, Nishihara A, Mishima K, Yamashita J, Shimizu K, Miyazawa K, et al. TGF- $\beta$ receptor kinase inhibitor enhances growth and integrity of embryonic stem cell-derived endothelial cells. J Cell Biol 2003;163:1303-11.

[143] Sheppard D. Roles of $\alpha \mathrm{v}$ integrins in vascular biology and pulmonary pathology. Curr Opin Cell Biol 2004;16:552-7.

[144] Xu L, Massague J. Nucleocytoplasmic shuttling of signal transducers. Nat Rev Mol Cell Biol 2004;5:1-11.

[145] Keski-Oja J, Koli K, von Melchner H. TGF- $\beta$ activation by traction? Trends Cell Biol 2004;14:657-9.

[146] Gumienny TL, Padgett RW. The other side of TGF- $\beta$ superfamily signal regulation: thinking outside the cell. Trends Endocr Metab 2002;13:295-9.

[147] Pardoux C, Derynck R. JNK regulates expression and autocrine signaling of TGF- $\beta 1$. Mol Cell 2004;15:170-1.

[148] Ventura J-J, Kennedy NJ, Flavell RA, Davis RJ. JNK regulates autocrine expression of TGF- $\beta 1$. Mol Cell 2004;15:269-78.

[149] Annes JP, Munger JS, Rifkin DB. Making sense of latent TGFß activation. J Cell Sci 2003;116:217-24.

[150] Rifkin DB. Latent transforming growth factor- $\beta$ (TGF- $\beta$ ) binding proteins: orchestrators of TGF- $\beta$ availability. J Biol Chem 2005;280: 7409-12.

[151] Piek E, Heldin C-H, ten Dijke P. Specificity, diversity, and regulation in TGF- $\beta$ superfamily signaling. FASEB J 1999;13:2105-24.

[152] Lebrin F, Deckers M, Bertolino P, ten Dijke P. TGF- $\beta$ receptor function in the endothelium. Cardiovasc Res 2005;65:599-608.

[153] Ge B, Gram H, Di Padova F, Huang B, New L, Ulevitch RJ, et al. MAPKK-independent activation of $\mathrm{p} 38 \alpha$ mediated by TAB1-dependent autophosphorylation of p38 $\alpha$. Science 2002;295:1291-4.

[154] Schiffer M, Mundel P, Shaw AS, Bottinger EP. A novel role for the adaptor molecule $\mathrm{CD} 2$-associated protein in transforming growth factor- $\beta$-induced apoptosis. J Biol Chem 2004;279:37004-12.
[155] Schiffer M, Mundel P, Shaw AS, Bottinger EP. A novel role for the adaptor molecule $\mathrm{CD} 2$-associated protein in tranforming growth factor- $\beta$-induced apoptosis. J Biol Chem 2004;279:3700412 .

[156] Razani B, Zhang XL, Bitzer M, von Gersdorff G, Bottinger EP, Lisanti MP. Caveolin-1 regulates transforming growth factor (TGF)$\beta /$ Smad signaling through an interaction with the TGF- $\beta$ type I receptor. J Biol Chem 2001;276:6727-38.

[157] Schwarz K, Simons M, Reiser J, Saleem MA, Faul C, Kriz W, et al. Podocin, a raft-associated component of the glomerular slit diaphragm, interacts with CD2AP and nephrin. J Clin Invest 2001; 108:1621-9.

[158] Dikic I. CIN85/CMS family of adaptor molecules. FEBS Lett 2002;529:110-5

[159] Kirsch KH, Georgescu M-M, Ishimaru S, Hanafusa H. CMS: An adapter molecule involved in cytoskeletal rearrangements. Proc Natl Acad Sci USA 1999;96:6211-6.

[160] Webb DJ, Donais K, Whitmore LA, Thomas SM, Turner CE, Parsons JT, et al. FAK-Src signalling through paxillin, ERK and MLCK regulates adhesion disassembly. Nat Cell Biol 2004;6:154-61.

[161] Lui WY, Mruk D, Lee WM, Cheng CY. Sertoli cell tight junction danamics: their regulation during spermatogenesis. Biol Reprod 2003;68:1087-97.

[162] Lui WY, Mruk DD, Lee WM, Cheng CY. Adherens junction dynamics in the testis and spermatogenesis. J Androl 2003;24:1-14.

[163] Grima J, Silvestrini B, Cheng CY. Reversible inhibition of spermatogenesis in rats using a new male contraceptive, 1-(2,4-dichlorobenzyl)-indazole-3-carbohydrazide. Biol Reprod 2001;64:1500-8.

[164] Cheng CY, Silvestrini B, Grima J, Mo M-Y, Zhu L-J, Jahansson E, et al. Two new male contraceptives exert their effects by depleting germ cells prematurely from the testis. Biol Reprod 2001;65:449-61.

[165] Grima J, Wong CCS, Zhu L-J, Zong S-D, Cheng CY. Testin secreted by Sertoli cells is associated with the cell surface, and its expression correlates with the disruption of Sertoli-germ cell junctions but not the inter-Sertoli tight junction. J Biol Chem 1998;273:21040-53.

[166] Grima J, Cheng CY. Testin induction: the role of cyclic $3^{\prime}, 5^{\prime}$ adenosine monophosphate/protein kinase A signaling in the regulation of basal and lonidamine-induced testin expression by rat Sertoli cells. Biol Reprod 2000;63:1648-60.

[167] Lui WY, Lee WM, Cheng CY. Sertoli-germ cell adherens junction dynamics in the testis are regulated by RhoB GTPase via the ROCK/ LIMK signaling pathway. Biol Reprod 2003;68:2189-206.

[168] Chen Y-M, Lee NPY, Mruk DD, Lee WM, Cheng CY. Fer kinase/ FerT and adherens junction dynamics in the testis: an in vitro and in vivo study. Biol Reprod 2003;69:656-72.

[169] Werner S, Grose R. Regulation of wound healing by growth factors and cytokines. Physiol Rev 2003;83:835-70.

[170] Sahai E. Mechanisms of cancer cell invasion. Curr Opin Genet Dev 2005;15:87-96.

[171] Zalups RK, Ahmad S. Molecular handling of cadmium in transporting epithelia. Toxicol Appl Pharmac 2003;186:163-88.

[172] Waisberg M, Joseph P, Hale B, Beyersmann D. Molecular and cellular mechanisms of cadmium carcinogenesis. Toxicology 2003;192:95117.

[173] Henson MC, Chedrese PJ. Endocrine disruption by cadmium, a common environmental toxicant with paradoxical effects on reproduction. Expt Biol Med 2004;229:383-92.

[174] Johnson MD, Kenney N, Stoica A, Hilakivi-Clarke L, Singh B, Chepko G, et al. Cadmium mimics the in vivo effects of estrogen in the uterus and mammary gland. Nat Med 2003;9:1081-4.

[175] Jin YH, Clark AB, Slebos RJC, Al-Refai H, Taylor JA, Kunkel TA, et al. Cadmium is a mutagen that acts by inhibiting mismatch repair. Nat Genet 2003:34:326-9.

[176] Dalton TP, He L, Wang B, Miller ML, Jin L, Stringer KF, et al. Identification of mouse SLC39A8 as the transporter responsible for cadmium-induced toxicity in the testis. Proc Natl Acad Sci USA 2005;102:3401-6. 
[177] Fiorini C, Tilloy-Ellul A, Schevalier S, Charuel C, Pointis G. Sertoli cell junctional proteins as early targets for different classes of reproductive toxicants. Reprod Toxicol 2004;18:413-21.

[178] Chung NPY, Cheng CY. Is cadmium chloride-induced inter-Sertoli tight junction permeability barrier disruption a suitable in vitro model to study the events of junctional disassembly during spermatogenesis in the rat testis? Endocrinology 2001;142:1878-88.

[179] Hew KW, Heath GL, Jiwa AH, Welsh MJ. Cadmium in vivo causes disruption of tight junction-associated microfilaments in rat Sertoli cells. Biol Reprod 1993;49:840-9.

[180] Gray LE, Ostby J, Furr J, Wolf CJ, Lambright C, Parks L, et al. Effects of environmental antiandrogens on reproductive development in experimental animals. Hum Reprod Update 2001;7:248-64.

[181] Boekelheide K, Johnson KJ, Richburg JH. Sertoli cell toxicants. In: Skinner MK, Griswold MD, editors. Sertoli cell biology. San Diego: Elsevier Academic Press; 2005. p. 345-82.

[182] Toyama Y, Suzuki-Toyota F, Maekawa M, Ito C, Toshimori K. Adverse effects of bisphenol A to spermiogenesis in mice and rats. Arch Histol Cytol 2004;67:373-81.

[183] Fisher JS. Environmental anti-androgens and male reproductive health: focus on phthalates and testicular dysgenesis syndrome. Reproduction 2004;127:305-15.

[184] Kelce WR, Monosson E, Gamcsik MP, Laws SC, Gray LEJ. Environmental hormone disruptors: evidence that vinclozolin developmental toxicity is mediated by antiandrogenic metabolites. Toxicol Appl Pharmacol 1994;126.

[185] Wong C-I, Kelce WR, Sar M, Wilson EM. Androgen receptor antagonist versus agonist activities of the fungicide vinclozolin relative to hydroxyflutamide. J Biol Chem 1995;270:19998-20003.

[186] Foster PMD, Mylchreest E, Gaido KW, Sar M. Effects of phthalate esters on the developing reproductive tract of male rats. Hum Reprod Update 2001;7:231-5.

[187] Creasy DM, Beech LM, Gray TJ, Butler WH. The ultrastructural effects of di- $n$-pentyl phthalate on the testis of the mature rats. Exp Mol Pathol 1987;46:357-71.

[188] Creasy DM, Foster JR, Foster PM. The morphological development of di- $N$-pentyl phthalate induced testicular atrophy in the rat. J Pathol 1983;139:309-21.

[189] Hotchkiss AK, Ostby JS, Vandenbergh JG, Gray J, Earl L. An environmental antiandrogen, vinclozolin, alters the organization of play behavior. Physiol Behav 2003;79:151-6.

[190] Gray LEJ, Ostby J, Monosson E, Kelce WR. Environmental antiandrogens: low doses of the fungicide vinclozolin alter sexual differentiation of the male rat. Toxicol Ind Health 1999;15:48-64.

[191] Yu WJ, Lee BJ, Nam SY, Ahn B, Hong JT, Do JC, et al. Reproductive disorders in pubertal and adult phase of the male rats exposed to vinclozolin during puberty. J Vet Med Sci 2004;66:847-53.

[192] Kubota K, Ohsako S, Kurosawa S, Takeda K, Qing W, Sakaue M, et al. Effects of vinclozolin administration on sperm production and testosterone biosynthetic pathway in adult male rat. J Reprod Dev 2003;49:403-12.

[193] Venkiteswaran K, Xiao K, Summers S, Calkins CC, Vincent PA, Pumiglia K, et al. Regulation of endothelial barrier function and growth by VE-cadherin, plakoglobin, and $\beta$-catenin. Am J Physiol Cell Physiol 2002;283:C811-21.

[194] Troxell ML, Chen Y-T, Cobb N, Nelson WJ, Marrs JA. Cadherin function in junctional complex rearrangement and posttranslational control of cadherin expression. Am J Physiol Cell Physiol 1999; 276:C404-18.

[195] Man Y, Hart VJ, Ring CJA, Sanjar S, West MR. Loss of epithelial integrity resulting from E-cadherin dysfunction predisposes airway epithelial cells to adenoviral infection. Am J Respir Cell Mol Biol 2000;23:610-7.

[196] Guo X, Rao JN, Liu L, Zou TT, Turner DJ, Bass BL, et al. Regulation of adherens junctions and epithelial paracellular permeability: a novel function for polyamines. Am J Physiol Cell Physiol 2003; 285:C1174-87.
[197] Gassler N, Rohr C, Schneider A, Kartenbeck J, Bach A, Obermuller $\mathrm{N}$, et al. Inflammatory bowel disease is associated with changes of enterocytic junctions. Am J Physiol Gastrointest Liver Physiol 2001;281:G216-28.

[198] Toyama Y, Yuasa S. Effects of neonatal administration of $17 \beta$ estradiol, $\beta$-estradiol 3-benzoate, or bisphenol $\mathrm{A}$ on mouse and rat spermatogenesis. Reprod Toxicol 2004;19:181-8.

[199] Li LH, Heindel JJ. Sertoli cell toxicants. In: Korach KS, editor. Reproductive and developmental toxicology. New York: Dekker Marcel; 1998. p. 655-91.

[200] Setchell BP, Waites GMH. Changes in the permeability of testicular capillaries and of the "blood-testis barrier" after injection of cadmium chloride in the rat. J Endocrinol 1970;47:81-6.

[201] Kagi J, Schaffer A. Biochemistry of metallothionein. Biochemistry 1988;27:8509-15.

[202] Nath R, Kambadur R, Gulati S, Paliwal V, Sharma M. Molecular aspects, physiological function, and clinical significance of metallothioneins. Crit Rev Food Nutr 1988;27:41-85.

[203] Nordberg G. Cadmium metabolism and toxicity. Environ Physiol Biochem 1972;2:7-36.

[204] Vallee B. The function of metallothionein. Neurochem Int 1995;27: $23-33$.

[205] Waalkes M, Goering P. Metallothionein and other cadmium-binding proteins: Recent developments. Chem Res Toxicol 1990;3:281-8.

[206] Sciavolino P, Lee T, Vilcek J. Overexpression of metallothionein confers resistance to the cytotoxic effect of TNF with cadmium in MCF-7 breast carcinoma cells. Lymphokine Cytokine Res 1992;11: 265-70.

[207] Dufresne J, Cyr D. Effects of short-term methylmercury exposure on metallothionein mRNA levels in the testis and epididymis of the rat. J Androl 1999;20:769-78.

[208] Suzuki J, Kodama N, Molotkov A, Aoko E, Tohyama C. Isolation and identification of metallothionein isoforms (MT-1 and MP-2) in the rat testis. Biochem J 1998;334:695-701.

[209] Sugihara T, Wadhwa R, Kaul S, Mitsui Y. A novel testis-specific metallothionein-like protein, tesmin, is an early marker of male germ cell differentiation. Genomics 1999;57:130-6.

[210] Ren X, Zhou Y, Zhang J, Feng W, Jiao B. Metallothionein gene expression under different time in testicular Sertoli and spermatogenic cells of rats treated with cadmium. Reprod Toxicol 2003;17:219-27.

[211] Coogan T, Shiraishi N, Waalkes M. Minimal basal activity and lack of metal-induced activation of the metallothionein gene correlates with lobe-specific sensitivity to the carcinogenic effects of cadmium in the rat prostate. Toxicol Appl Pharmacol 1995;132:164-73.

[212] Coogan T, Shiraishi N, Waalkes M. Metallothionein gene expression in the reproductive tissues of the Wistar rat: Effects of treatment with metals and glucocorticoids. Toxic Subst Mech 1997;16:357-70.

[213] Lee K, Lau K, Ho S. Effects of cadmium on metallothionein-I and metallothionein-II mRNA expression in rat ventral, lateral, and dorsal prostatic lobes: Quantification by competitive RT-PCR. Toxicol Appl Pharmacol 1999;154:20-7.

[214] Prozialeck WC. Evidence that E-cadherin may be a target for cadmium toxicity in epithelial cells. Toxicol Appl Pharmacol 2000;164:231-49.

[215] Prozialeck WC, Lamar PC. Interaction of cadmium $\left(\mathrm{Cd}^{2+}\right)$ with a 13residue polypeptide analog of a putative calcium-binding motif of $\mathrm{E}$ cadherin. Biochim Biophys Acta 1999;1451:93-100.

[216] Prozialeck WC, Niewenhuis RJ. Cadmium $\left(\mathrm{Cd}^{2+}\right)$ disrupts intercellular junctions and actin filaments in LLC-PK1 cells. Toxicol Appl Pharmacol 1991;107:81-97.

[217] Plow EF, Haas TA, Zhang L, Loftus J, Smith JW. Ligand binding to integrins. J Biol Chem 2000;275:21785-8.

[218] De SK, Chen HL, Pace JL, Hunt JS, Terranova PF, Enders GC. Expression of tumor necrosis factor- $\alpha$ in mouse spermatogenic cells. Endocrinology 1993;133:389-96.

[219] Montell DJ. Border-cell migration: the race is on. Nat Rev Mol Cell Biol 2003;4:13-24. 
2018
[220] Matzuk MM. Germ-line immortality. Proc Natl Acad Sci USA 2004;101:16395-6.

[221] MacLean IIJA, Chen MA, Wayne CM, Bruce SR, Rao M, Meistrich ML, et al. Rhox: a new homeobox gene cluster. Cell 2005;120:369-82.

[222] De Gendt K, Swinnen JV, Saunders PTK, Schoonjans L, Dewerchin M, Devos A, et al. A Sertoli cell-selective knockout of the androgen receptor causes spermatogenic arrest in meiosis. Proc Natl Acad Sci USA 2004;101:1327-32.

[223] Stamatovic SM, Keep RF, Kunkel SL, Andjelkovic AV. Potential role of MCP-1 in endothelial cell tight junction 'opening': signaling via Rho and Rho kinase. J Cell Sci 2003;116:4615-28.

[224] Pedram A, Razandi M, Levin ER. Deciphering vascular endothelial cell growth factor/vascular permeability factor signaling to vascular permeability. Inhibition by atrial natriuretic peptide. J Biol Chem 2002;277:44385-98.

[225] Ahdieh M, Vandenbos T, Youakim A. Lung epithelial barrier function and wound healing are decreased by IL-4 and IL-13 and enhanced by IFN- $\gamma$. Am J Physiol Cell Physiol 2001;281:C2029-38.

[226] Kagami S, Kuhara T, Yasutomo K, Okada K, Loster K, Reutter W, et al. Transforming growth factor- $\beta$ (TGF- $\beta$ ) stimulates the expression of $\beta 1$ integrins and adhesion by rat mesangial cells. Exp Cell Res 1996;229:1-6.

[227] Tian YC, Fraser D, Attisano L, Phillips AO. TGF- $\beta 1$-mediated alterations of renal proximal tubular epithelial cell phenotype. Am J Physiol Renal Physiol 2003;285:F130-42.

[228] de Kretser DM, Buzzard JJ, Okuma Y, O’Connor AE, Hayashi T, Lin $\mathrm{S}-\mathrm{Y}$, et al. The role of activin, follistatin and inhibin in testicular physiology. Mol Cell Endocr 2004;225:57-64.

[229] Shimasaki S, Moore RK, Otsuka F, Erickson GF. The bone morphogenetic protein system in mammalian reproduction. Endocr Rev 2004;25:72-101.

[230] Pellegrini M, Grimaldi P, Rossi P, Geremia R, Dolci S. Developmental expression of BMP4/ALK3/SMAD5 signaling pathway in the mouse testis: a potential role of BMP4 in spermatogonia differentiation. J Cell Sci 2003;116:3363-72.

[231] Hua J, Chen Y-X, Wang D, Qi X, Li T-G, Hao J, et al. Developmental expression and function of Bmp4 in spermatogenesis and in maintaining epididymal integrity. Dev Biol 2004;276:158-71.

[232] Pasparakis M, Alexopoulou L, Episkopou V, Kollias G. Immune and inflammatory responses in TNF $\alpha$-deficient mice: a critical requirement for TNF $\alpha$ in the formation of primary B cell follicles, follicular dendritic cell networks and germinal centers, and in the maturation of the humoral immune response. J Exp Med 1996;184:1397-411.

[233] D’Alessio A, Riccioli A, Lauretti P, Padula F, Muciaccia B, De Cesaris P, et al. Testicular FasL is expressed by sperm cells. Proc Natl Acad Sci USA 2001;98:3316-21.

[234] Lee J, Richburg JH, Younkin SC, Boekelheide K. The Fas system is a key regulator of germ cell apoptosis in the testis. Endocrinology 1997;138:2081-8.

[235] Adachi M, Suematsu S, Kondo T, Ogasawara J, Tanaka T, Yoshida N, et al. Targeted mutation in the Fas gene causes hyperplasia in peripheral lymphoid organs and liver. 1995;11:294-300.

[236] Grataroli R, Vindrieux D, Gougeon A, Benahmed M. Expression of tumor necrosis factor- $\alpha$-related apoptosis-inducing ligand and its receptors in rat testis during development. Biol Reprod 2002;66: 1707-15.

[237] Cretney E, Takeda K, Yagita H, Glaccum M, Peschon JJ, Smyth MJ. Increased susceptibility to tumor initiation and metastasis in TNFrelated apoptosis-inducing ligand-deficient mice. J Immunol 2002; 168:1356-61.

[238] Luetteke N, Qiu T, Fenton S, Troyer K, Riedel R, Chang A, et al. Targeted inactivation of the EGF and amphiregulin genes reveals distinct roles for EGF receptor ligands in mouse mammary gland development. Development 1999;126:2739-50.

[239] Radhakrishnan B, Oke B, Papadopoulos V, DiAugustine R, SuarezQuian C. Characterization of epidermal growth factor in mouse testis. Endocrinology 1992;131:3091-9.
[240] Wahab-Wahlgren A, Martinelle N, Holst M, Jahnukainen K, Parvinen M, Soder O. EGF stimulates rat spermatogonial DNA synthesis in seminiferous tubule segments in vitro. Mol Cell Endocr 2003;201: 39-46.

[241] Bottcher RT, Niehrs C. Fibroblast growth factor signaling during early vertebrate development. Endocr Rev 2005;26:63-77.

[242] Yamamoto H, Ochiya T, Tamamushi S, Toriyama-Baba H, Takahama Y, Hirai K, et al. HST-1/FGF-4 gene activation induces spermatogenesis and prevents adriamycin-induced testicular toxicity. Oncogene 2002;21:899-908.

[243] Yamamoto H, Ochiya T, Takahama Y, Ishii Y, Osumi N, Sakamoto H, et al. Detection of spatial localization of Hst-1/Fgf-4 gene expression in brain and testis from adult mice. Oncogene 2000;19:3805-10.

[244] Ricci G, Catizone A, Galdieri M. Pleiotropic activity of hepatocyte growth factor during embryonic mouse testis development. Mech Dev 2002;118:19-28.

[245] Catizone A, Ricci G, Galdieri M. Expression and functional role of hepatocyte growth factor receptor (C-MET) during postnatal rat testis development. Endocrinology 2001;142:1828-34.

[246] Uehara Y, Minowa O, Mori C, Shiota K, Kuno J, Noda T, et al. Placental defect and embryonic lethality in mice lacking hepatocyte growth factor/scatter factor. Nature 1995;373:702-5.

[247] Meinhardt A, Bacher M, Wennemuth G, Eickhoff R, Hedger M, Macrophage migration inhibitory factor (MIF) as a paracrine mediator in the interaction of testicular somatic cells. 2000;32:46-48.

[248] Honma N, Koseki H, Akasaka T, Nakayama T, Taniguchi M, Serizawa I, et al. Deficiency of the macrophage migration inhibitory factor gene has no significant effect on endotoxaemia. Immunology 2000;100:84-90.

[249] Marziali G, Lazzaro D, Sorrentino V. Binding of germ cells to mutant $\mathrm{SI}^{\mathrm{d}}$ Sertoli cells is defective and is rescued by expression of the transmembrane form of the c-kit ligand. Dev Biol 1993;157:182-90.

[250] Bedell MA, Zama AM. Genetic analysis of Kit ligand functions during mouse spermatogenesis. J Androl 2004;25:188-99.

[251] Nalbandian A, Dettin L, Dym M, Ravindranath N. Expression of vascular endothelial growth factor receptors during male germ cell differentiation in the mouse. Biol Reprod 2003;69:985-94.

[252] Rudolfsson SH, Wikstrom P, Jonsson A, Collin O, Bergh A. Hormonal regulation and functional role of vascular endothelial growth factor A in the rat testis. Biol Reprod 2004;70:340-7.

[253] Ferrara N, Carver-Moore K, Chen H, Dowd M, Lu L, O'Shea KS, et al. Heterozygous embryonic lethality induced by targeted inactivation of the VEGF gene. Nature 1996;380:439-42.

[254] Horai R, Asano M, Sudo K, Kanuka H, Suzuki M, Nishihara M, et al. Production of mice deficient in genes for interleukin (IL)-1 $\alpha$, IL-1 $\beta$, IL- $1 \alpha / \beta$, and IL-1 receptor antagonist shows that IL- $1 \beta$ is crucial in turpentine-induced fever development and glucocorticoid secretion. J Exp Med 1998;187:1463-75.

[255] Hedger MP, Meinhardt A. Cytokines and the immune-testicular axis. J Reprod Immunol 2003;58:1-26.

[256] Dalton D. IFN- $\gamma$ and IFN- $\gamma$ receptor knockout mice. In: Fantuzzi G, editor. Cytokine knockouts. Totowa, NJ: Humana Press; 2003 . p. 347-59.

[257] Dejucq N, Lienard M-O, Guillaume E, Dorval I, Jegou B. Expression of interferons- $\alpha$ and $-\gamma$ in testicular interstitial tissue and spermatogonia of the rat. Endocrinology 1998;139:3081-7.

[258] Pogach LM, Lee Y, Gould S, Giglio W, Meyenhofer M, Huang HF. Characterization of cis-platinum-induced Sertoli cell dysfunction in rodents. Toxicol Appl Pharmacol 1989;98:350-61.

[259] Peterson PM, Giwercman A, Skakkebaek NE, Rorth M. Gonadal function in men with testicular cancer. Semin Oncol 1998;25:224-33.

[260] Wiebe JP, Kowalik A, Gallardi RL, Egeler O, Clubb BH. Glycerol disrupts tight junction-associated actin microfilaments, occludin, and microtubules in Sertoli cells. J Androl 2000;21:625-35.

[261] Wiebe JP, Barr KJ, Buckingham KD, Gedded PD, Kudo PA. Prospects of a male contraceptive based on selective antispermatogenic action of 1,2,3-trihydroxypropane (THP; glycerol). In: Zatuchni GI, 
Goldsmith A, Spiler AJM, Sciarra JJ, editors. Male contraception:advances and future prospects. Philadelphia: Harper and Row; 1986. p. 252-70.

[262] Chung NPY, Mruk D, Mo M-Y, Lee WM, Cheng CY. A 22-amino acid synthetic peptide corresponding to the second extracellular loop of rat occludin perturbs the blood-testis barrier and disrupts spermatogenesis reversibly in vivo. Biol Reprod 2001;65:1340-51.

[263] Waites GM, Wang C, Griffin PD. Gossypol: reasons for its failure to be accepted as a safe, reversible male antifertility drug. Int J Androl 1998;21:8-12.

[264] Qian S, Wang Z. Gossypol: a potential antifertility agent for males. Annu Rev Pharmacol Toxicol 1984;24:329-60.

[265] Pelletier RM, Friend DS. Sertoli cell junctional complexes in gossypol-treated neonatal and adult guinea pigs. J Androl 1986;7: 127-39.

[266] Silvestrini B, Palazzo G, De Gregorio M. Lonidamine and related compounds. Prog Med Chem 1984;21:111-35.

[267] O’Donnell L, Stanton PG, Bartles JR, Robertson DM. Sertoli cell ectoplasmic specializations in the seminiferous epithelium of the testosterone-suppressed adult rat. Biol Reprod 2000;63:99-108.

[268] McLachlan RI, O’Donnell L, Meachem SJ, Stanton PG, Kretser DMD, Pratis K, et al. Hormonal regulation of spermatogenesis in primates and man: insights for development of the male hormonal contraceptive. J Androl 2002;23:149-62.

[269] Kelce WR, Lambright CR, Gray J, Earl L, Roberts KP. Vinclozolin and $\mathrm{p}, \mathrm{p}^{\prime}$-DDE alter androgen-dependent gene expression: in vivo confirmation of an androgen receptor-mediated mechanism. Toxicol Appl Pharmacol 1997;142:192-200.

[270] Uzumcu M, Suzuki H, Skinner MK. Effect of the anti-androgenic endocrine disruptor vinclozolin on embryonic testis cord formation and postnatal testis development and function. Reprod Toxicol 2004; 18:765-74.

[271] Ashby J, Tinwell H, Lefevre PA, Joiner R, Haseman J. The effect on sperm production in adult Sprague-Dawley rats exposed by gavage to bisphenol A between postnatal days 91-97. Toxicol Sci 2003;74: 129-38.

[272] Williams K, McKinnell C, Saunders PTK, Walker M, Fisher JS, Turner $\mathrm{KJ}$, et al. Neonatal exposure to potent and environmental oestrogens and abnormalities of the male reproductive system in the rat: evidence for importance of the androgen-oestrogen balance and assessment of the relevance to man. Hum Reprod Update 2001;7:236-47.

[273] Wang Y, Thuillier R, Culty M. Prenatal estrogen exposure differentially affects estrogen receptor-associated proteins in rat testis gonocytes. Biol Reprod 2004;71:1652-64. 